\title{
Does hearing loss lead to dementia? A review of the literature
}

\author{
Yosra Nadhimi ${ }^{1}$ and Daniel A. Llano $1,2,3,4$
}

1. Molecular and Cellular Biology, University of Illinois at Urbana-Champaign

2. Neuroscience Program, University of Illinois at Urbana-Champaign

3. Carle Neuroscience Institute, Urbana, IL

4. Beckman Institute for Advanced Science and Technology, Urbana, IL

Acknowledgments: DAL was supported by DC013073 and AG059103. The authors thank Dr. Justin Rhodes (Department of Psychology, University of Illinois at Urbana-Champaign) for his critical review of this manuscript. The authors thank Drs. Andrew Ford and Osvaldo Almeida (University of Western Australia) and Dr. Tres Thompson (University of Texas, Dallas) for providing high-resolution versions of Figures 1 and 2, respectively and Dr. Xiaomei Liao for permission to use their data for Figure 3.

\section{Abstract:}

Recent studies have revealed a correlation between aging-related hearing loss and the likelihood of developing Alzheimer Disease. However, it is not yet known if the correlation simply reflects the fact that these two disorders share common risk factors or whether there is a causal link between them. The answer to this question carries therapeutic implications. Unfortunately, it is not possible to study the question of causality between aging-related hearing loss and dementia in human subjects. Here, we evaluate the research surrounding induced-hearing loss in animal models on non-auditory cognition to help infer if there is any causal evidence linking hearing loss and a more general dementia. We find ample evidence that induction of hearing loss in animals produces cognitive decline, particularly hippocampal dysfunction. The data suggest that noiseexposure produces a toxic milieu in the hippocampus consisting of a spike in glucocorticoid levels, elevations of mediators of oxidative stress and excitotoxicity, which as a consequence induce cessation of neurogenesis, synaptic loss and tau hyperphosphorylation. These data suggest that hearing loss can lead to pathological hallmarks similar to those seen in Alzheimer's Disease and other dementias. However, the rodent data do not establish that hearing loss on its own can induce a progressive degenerative dementing illness. Therefore, we conclude that an additional "hit", such as aging, APOE genotype, microvascular disease or others, may be necessary to trigger an ongoing degenerative process such as Alzheimer Disease. 


\subsection{Introduction:}

Alzheimer's Disease (AD) and Aging-Related Hearing Loss (ARHL) are diseases of rapidly increasing prevalence and are of major societal importance. Both disorders rob people of their quality of life, and neither has adequate treatments. Approximately half of the population over the age of 70 suffer from $A R H L$ and $10-15 \%$ have AD, and these numbers are growing. Recently, there has been an explosion of epidemiological studies suggesting that aging-related cognitive declines, AD and ARHL are associated (Ford et al., 2018; Golub et al., 2017; Gurgel et al., 2014; Heywood et al., 2017; Lin et al., 2011a; Lin et al., 2011b; Lin et al., 2013; Thomson et al., 2017). Most of these studies have revealed a strong association between AHRL and cognitive impairment despite controlling for multiple potentially confounding variables, such as age, sex, apolipoprotein E4 status and cardiovascular risk factors. For example, in a recent study of nearly 38,000 elderly Australian men without dementia followed up to 17 years, those with hearing loss at entry had a $69 \%$ increased risk of developing dementia over the study period, when adjusted for age and aging-related morbidities (see Figure 1 for Kaplan-Meier curve (Ford et al., 2018)). The other studies cited above have similar risk profiles, suggesting that ARHL may be an independent risk factor for the development of cognitive impairment. Because multiple treatments exist to improve auditory function in individuals with $\mathrm{ARHL}$ (hearing aids, aural rehabilitation, cochlear implants, etc.), ARHL may, in fact, be a modifiable risk factor for the development of dementia. However, currently, less than $20 \%$ of individuals that could benefit from hearing aids obtain them (Chien et al., 2012; Popelka et al., 1998), suggesting that there may be a large untapped resource available to mitigate the risk of developing AD. Thus, uncovering a common pathological substrate that links $A R H L$ and $A D$ would represent a major breakthrough for the development of new therapies for both disorders because it would merge large bodies of work and their drug targets. In addition, finding an etiological link between ARHL and AD would open the door for sophisticated psychoacoustic measurements to be used to help diagnose and track progress and treatment-responses in AD (Swords et al., 2018). Therefore, identifying the mechanisms that underlie the epidemiological association between $A R H L$ and $A D$ carries significant implications.

Loss of function in other sensory systems, such as vision, may also be linked to AD, but the nature of the relationship is less clear. Several studies have found an epidemiological link between aging-related vision loss and AD (Chen et al., 2017; Lin et al., 2014; Mangione et al., 1993). However, other factors may confound these data. First, glaucoma, which is the leading non-reversible cause of blindness in both the U.S. and overseas, as well as macular degeneration 
another major cause of aging-associated vision loss, are both associated with retinal amyloid beta deposition (McKinnon, 2003; Mullins et al., 2000). This relationship suggests that a shared propensity towards pathological proteostasis may underlie the relationship, rather than a causal link between vision loss and subsequent hippocampal dysfunction. In addition, many of the timed tasks used to measure cognitive function such as Stroop, Trails B, digit-symbol substitution, etc, are require vision, and diminished visual signal-to-noise ratio may lengthen processing times, thus diminishing performance. Therefore, more work is needed to clarify the nature of the relationship between vision and $A D$.

One major scientific unresolved problem is whether the connection between AD and ARHL is simply related to common risk factors (e.g., aging, microvascular disease, diabetes, etc.), or whether a causal relationship exists between the two. Answering this question is critical because if the two are simply related due to common risk factors, then approaches that involve aggressively managing those risk factors would be an optimal strategy to mitigate AD and ARHL. However, if, for example, hearing loss on its own exacerbated AD pathology, then a broad array of aggressive interventions ranging from auditory rehabilitation, to early use of hearing aids or even cochlear implants, may be justified as a means to diminish AD pathology.

Unfortunately, this question cannot be answered in human subjects. To make inferences about causation, an animal model is needed so that interventions can be done, such as the induction of hearing loss, to then examine the impact of hearing loss on non-cognitive function. The reverse is also possible. That is, AD pathology could lead to peripheral hearing loss, as has been suggested in a mouse model of amyloid beta over-expression (O'Leary et al., 2017), though the link between such models and the most common sporadic forms of $A D$ is still uncertain. Here, we evaluate the research surrounding induced hearing loss in animals to determine if there is a causal link between hearing loss and non-auditory cognition. The focus of this literature review is on the impact of hearing loss on hippocampal function, since loss of hippocampal structural damage and dysfunction are core findings in AD (Barnes et al., 2009; Scheff et al., 2007; Tromp et al., 2015). We begin with an evaluation of the findings regarding the association between hearing loss and cognitive decline in animal studies. We examine how lesioning the peripheral auditory apparatus leads to worsened performance on behavioral tasks that measure hippocampal function, such as the Morris Water Maze (MWM) task, radial-arm maze (RAM) task and object recognition (OR) tasks. We exclude studies that examined the relationship between aging-related hearing loss and hippocampal function in aged animals since aging serves as a confounding variable. We also exclude studies that used systemic administration of drugs, such as aminoglycosides or salicylates, to cause hearing loss, since their effects may extend to the 
brain, confounding the link between hearing loss and hippocampal dysfunction. We therefore focus on studies that injure the peripheral hearing apparatus with noise. Although other methods of deafferentation exist, such as ear plugging or surgical disruption of the auditory periphery, there is not yet an extensive literature examining their effects on non-auditory cognitive function. Noise exposure also provides a way to titrate the peripheral loss based on the severity of the exposure. Therefore, in the following sections, we separate the findings into animals that have received acute (a single exposure) vs. subacute (defined here as up to 30 days of exposure) exposure to noise. Subacute exposure would be expected to produce longer-lasting changes in hippocampal function, but may show diminished changes related to the acute stress of one-time noise exposure. The second goal will be to discuss the potential mechanistic links underlying these experimental results. We will conclude by discussing potential future directions of this research, to further study this topic. The studies involving induced hearing loss and hippocampal dysfunction that are reviewed and their key findings are summarized in Table 1.

\subsection{The impact of acute noise exposure}

\subsection{Acute noise exposure and hippocampal function:}

Several studies focused on the impact of acute noise exposure on short-term hippocampal physiology and neurochemistry. For example, Goble et al. evaluated the impact of 30 minutes of high-intensity sound exposure effect on the hippocampal place cells (Goble et al., 2009). The group used implanted recording electrodes in the hippocampus to measure changes in place cell maps, as well as the RAM test, to investigate for altered spatial memory. The investigators observed that in the ensuing 2-6 hours after intense noise exposure that rats demonstrated poor learning on a RAM task and that hippocampal place fields became expanded or duplicated (see Figure 2). In addition, long-term potentiation, long thought to be a substrate for learning and memory in the hippocampus (Whitlock et al., 2006), was found to be diminished over the first 24 hours after noise-exposure in a noise dose-dependent manner (De Deus et al., 2017). Despite the inhibition in long-term potentiation, the investigators did not observe significant changes in spatial memory function in these animals. Potential neurochemical correlates of these functional changes were examined by Cui et al. who employed acute noise exposure followed by high performance liquid chromatography, Western blotting, and immunohistochemistry in the hippocampus (Cui et al., 2012). Using homogenized hippocampal tissue, the investigators observed increased concentrations of glutamate and aspartate in the hippocampus as well as an increase in expression of the NMDA receptor subunit NR2B 30 minutes after noise exposure, and these levels remained elevated for 24 hours. The concentration of glycine remained stable for 
several hours and then increased 24 hours after noise stress. They also observed tau hyperphosphorylation in the dentate gyrus and CA1 region of the hippocampus following noise exposure. These three studies suggest that noise exposure causes a rapid and dramatic reorganization of inputs, neurochemistry and neuroplastic potential of the hippocampus, on time scales commensurate with other changes seen after noise exposure, such as changes in spontaneous and driven activity in the auditory cortex (Kimura et al., 1999; Norena et al., 2003). These changes are linked to behavioral manifestations (poor performance on RAM testing) and may be related to increased NMDA-receptor signaling in the hippocampus. Similar results have been seen in a model of accelerated aging-related hearing loss (C57BL/6 mice), which show elevated hippocampal NR2B expression relative to mice with intact hearing, and this elevation is associated with impaired hippocampal plasticity and item-place memory (Beckmann et al., 2020).

\subsection{Acute noise and hippocampal neurogenesis:}

Hippocampal neurogenesis in adults is thought to be important for learning and memory (Deng et al., 2010; Shors et al., 2001). Several studies have examined the impact of acute noise exposure on the production of new neurons in the adult hippocampus. For example, Kraus et al. examined 9 rats that were exposed unilaterally to high-intensity, narrow-band noise centered at $12 \mathrm{kHz}$ at $126 \mathrm{~dB}$ SPL under isoflurane anesthesia (Kraus et al., 2010) and observed a reduction in the number of neuronal precursor cells (doublecortin-positive) and proliferating neurons (Ki67positive) in the hippocampus. No hippocampal memory testing was done in this study, but the investigators did find behavioral evidence of tinnitus in some animals, and that tinnitus-like behavior was not linked to aberrant hippocampal neurogenesis. Tao et al. investigated if noise exposure during early development (postnatal day 15 mice) exerts a long term impact on cognitive function and neurogenesis two months later (Tao et al., 2015). They observed that the noiseexposure was associated with diminished performance on MWM compared to sham animals and similar to Kraus et al. observed that hippocampal neurogenesis (via doublecortin immunostaining) was reduced after noise exposure. Similarly, Liu et al. found that the mice with acute noiseexposure demonstrated slower learning on a MWM task and they observed a decrease in the hippocampal neurogenesis (via doublecortin and Ki67 immunostaining) of the noise group compared to the control (Liu et al., 2016). In addition, they observed that plasma corticosterone levels were higher in the noise-exposure group than the control immediately after noise exposure. However, when measured again three months, the plasma corticosterone level returned to normal. Superoxide dismutase, an enzyme that breaks down toxic oxygen radicals, and malondialdehyde, a marker of lipid peroxidation, were also elevated in the hippocampus 
immediately after noise exposure but recovered within one month. Using a similar noise-exposure paradigm, Liu et al. also evaluated the effect of noise-induced hearing loss on spatial learning and memory using the MWM task, as well as a battery of other measures of hippocampal tissue health (Liu et al., 2018). Similar to their 2016 study, mice exhibited diminished learning on the MWM task. They also found that noise exposure diminished the ability of training to rescue proliferating hippocampal neurons, diminished morphological complexity as well as a reduced transcription of immediate-early genes in the hippocampus while not altering the bank of hippocampal stem cells. Collectively, these data point to an ability of noise exposure to diminish the capacity for the hippocampus to produce new neurons, which may limit its ability to effectuate plastic changes in its synaptic organization in response to changing environmental demands.

\subsection{The impact of subacute noise exposure}

\subsection{Subacute noise exposure and hippocampal function:}

Several studies examined the impact of subacute noise exposure on hippocampal neurotransmitter levels and receptor expression. For example, Cui et al. (2009) and (2013) examined the effects of subacute noise exposure on spatial memory in Sprague-Dawley rats (using the MWM task), and its associated anatomical and biochemical changes in the hippocampus (specifically looking at its effect on NMDA Receptor 2B and tau phosphorylation) (Cui et al., 2009; Cui et al., 2013). The 2009 study showed that 30 days of noise exposure (100 $\mathrm{dB}$ white noise for 4 hours/day) significantly decreased spatial learning and memory performance compared to control. The rats underwent amino acid neurotransmitter (glutamic acid, GABA, aspartic acid, and glycine) assays from hippocampal tissue homogenates immediately after the last noise exposure. Brain sections were also evaluated by Nissl staining and immunohistochemistry was performed for NR2B. The researchers found that the concentration of glutamic acid increased significantly in the noise-exposure group, and that GABA decreased significantly. They also found the mean optical density of Nissl bodies (a marker of protein synthesis) to be reduced in CA1, dentate gyrus, and CA3 of the hippocampus, as well as significantly decreased expression of NR2B in those regions. They concluded that the impaired spatial memory in the noise-exposed animals may be related to excitotoxicity and reduced NR2B expression, and a diminishment in protein synthesis. Using a similar noise exposure paradigm, Cui et al. (2013) studied the effect of subacute noise exposure on the subsequent expression of NMDA receptor and tau phosphorylation in the hippocampus of rats. The authors again observed diminished NR2B expression along with an increase in tau hyperphosphorylation as well as 
TUNEL-positive neurons in the hippocampus of noise-exposed rats, suggesting that noiseinduced NMDA receptor downregulation as well as hippocampus apoptosis.

In another study examining the impact of subacute noise exposure on hippocampal neurochemistry, Chengzhi et al. (2011) exposed rats to moderate (80 dB) or severe (100 dB) noise for 30 days and evaluated the level of monoamine neurotransmitters in the hippocampus at one day or 40 days post-exposure (Chengzhi et al., 2011). They observed that the noise-exposure groups failed to reach the same level of performance as the normal controls in the MWM task and also found that the noise-exposed rats had a dose-dependent decrease in levels of dopamine, norepinephrine, and serotonin in their hippocampus. The researchers also found that the reduction in the neurotransmitters and impaired water maze task did recover over time; on the 30th day after noise-exposure the $80 \mathrm{~dB}$ SPL group was not different the controls, and by day 40 , the $100 \mathrm{~dB}$ SPL group also showed no differences than control. The authors conclude that their study shows that noise-exposure does induce cognitive difficulties, but that these recovered over time in parallel with changes in dopamine, norepinephrine and serotonin in the hippocampus. These changes in dopamine and serotonin are likely related to an increase in their turnover, as Haider et al., observed an increase in serotonin and dopamine metabolites in the hippocampus in parallel with a decline in memory function (Haider et al., 2012).

Several studies examined the impact of subacute noise exposure on hippocampal stem cells as well as metrics of hippocampal tissue health. For example, Cheng et al. (2011) investigated the effect of moderately intense white noise exposure ( $80 \mathrm{~dB}$ SPL for $2 \mathrm{~h} / \mathrm{day}$ ) on learning and memory in Kunming mice (Cheng et al., 2011). They also measured the levels of oxidative stress and phosphorylated-tau in the inferior colliculus, auditory cortex, and hippocampus, as these structures make up the acoustic lemniscal ascending pathway. They found that the latencies to find the platform in the MWM in the 1 and 3-week noise-exposed groups were significantly longer and that the swimming paths of the noise-exposed mice groups were longer and more complicated than the controls. They also found evidence of oxidative damage in the inferior colliculus, auditory cortex and hippocampus, as evidenced by a drop in the superoxide dismutase/malondialdehyde ratio, and found that this drop was strongest in the hippocampus. Consistent with several other studies referenced above, they observed an increase in hyperphosphorylated tau protein and a decline in unphosphorylated tau in the hippocampus. A subsequent study from the same group further investigated the structural and functional effects of noise exposure on the auditory cortex and hippocampus of mice (Cheng et al., 2016). Mice were exposed to moderate-intensity noise (80 dB SPL noise $(10 \mathrm{~Hz}-10 \mathrm{kHz})$ for 2 hours per day for 1-3 weeks), and then evaluated which brain region (auditory cortex or hippocampus) is more 
susceptible to this noise damage by measuring malondialdehyde and superoxide dismutase activity as well as tau phosphorylation. The investigators studied three week-old Kunming mice, divided into 4 groups, those exposed to one week to noise and their control, and then those exposed to three weeks of noise and their associated control. The authors found that there was significant peroxidation and tau hyperphosphorylation in the hippocampus of the mice with one or three weeks of noise exposure. The auditory cortex did not show any significant changes until three weeks of exposure to noise (Figure 3). The authors conclude that the hippocampus is more vulnerable to noise-related damage than the auditory cortex.

\subsection{Subacute noise and hippocampal neurogenesis:}

Similar to the acute noise exposure data, several studies reported that subacute noise exposure leads to diminished hippocampal neurogenesis. For example, Jauregui-Huerta et al. examined the impact of environmental noise exposure and its long-term effect on hippocampal cell proliferation (Jáuregui-Huerta et al., 2011). They exposed the 21-day old male Wistar rats for 15 days to an audiogram-fitted adaptation to a noisy environment. The noise ranged from $70 \mathrm{~dB}$ SPL for background to 85-103 dB SPL for the noisy events. Two months later they sacrificed the rats and evaluated the hippocampal cell proliferation using immunohistochemical analysis with 5 'bromodeoxiuridine as a marker. They also used blood samples from the rats to evaluate peripheral corticosterone levels immediately after noise exposure. They found that noiseexposure increased corticosterone at day 1, but not day 54 post-exposure, but decreased bromodeoxyuridine-positive cells in the dentate gyrus and CA3 of the hippocampus at 54 days post-exposure. More recently, Shukla et al. examined Sprague-Dawley that underwent noiseexposure with $100 \mathrm{~dB}$ SPL white noise for 2 hours per day for 15 days (Shukla et al., 2019). They found that the rats that underwent noise-exposure had longer latencies and longer path lengths on MWM testing as well as diminished DCX- and Ki67 positive cells in the hippocampus, consistent with previous work showing that acute noise exposure causes diminished hippocampal neurogenesis (Kraus et al., 2010; Liu et al., 2016; Liu et al., 2018; Tao et al., 2015).

Whereas virtually all studies on noise exposure and its effects on hippocampal function had focused on the impact over relatively short durations (hours to weeks post-exposure), two studies by Park et al. examined the impact of noise exposure 6-12 months post-exposure (Park et al., 2016; Park et al., 2018). In the 2016 study, 24 male C57BL/6J 1 month old mice were exposed to continuous white noise at $100 \mathrm{~dB}$ SPL for 60 min daily for a 20 day period. At 6 months post-noise exposure, animals showed increased total trial time and working memory errors and lowered correct entry ratios on RAM, as well as diminished discrimination index measured using 
novel object recognition. The 2018 study extended the follow-up of the mice to 9 and 12 months to evaluate the long-term effects of noise-induced hearing loss on cognition, and also examined hippocampal phosphorylated tau expression and lipofuscin in the noise-exposed mice. Performance on RAM (working memory errors and correct entry ratios) worsened up to 9 months post-exposure, then improved for working memory errors at 12 months. Discrimination index on novel object recognition was worse at 12 months post-exposure in the noise compared to the control group. The finding that the working memory impairment was reversible, but that recognition memory dysfunction was permanent, suggests that the effects of noise on different aspects of cognition are separable. After the behavioral tests at 12 months, they observed that the noise-induced hearing loss mice exhibited higher levels of phosphorylated tau and large lipofuscin granule area (a marker of brain aging (Mann et al., 1974; Moreno-García et al., 2018)) in the hippocampus.

\subsection{Acute vs. subacute noise exposure}

Several studies examined the impact of both acute and subacute noise exposure on hippocampal function. Manikandan et al., measured the impact of 1, 15 or 30 days of noise stress on memory alteration by examining RAM performance, brain antioxidant levels, free radical scavenging enzyme activity, and plasma corticosterone in rats (after the noise-stress for different durations), as well as performing a dendritic count of the medial prefrontal cortex and hippocampus 30 days following noise stress (Manikandan et al., 2006). The investigators found that the working and reference memory errors increased significantly in the noise-exposed rats compared to the controls, though did not differentiate based on duration of noise exposure. They also found that noise-exposed mice had increased plasma corticosterone levels, increased hippocampal lipid peroxidation, superoxide dismutase, glutathione peroxidase, catalase and acetylcholinesterase after one day of noise stress. All of these values gradually diminished towards normal values as the duration of noise exposure increased from 1, to 15 and then to 30 days. Hippocampal levels of glutathione (an antioxidant), remained low across all time points, though the 15 and 30 day values were not significantly lower than baseline. These data suggest that adaptation to chronic noise exposure occurs, and is reflected in metrics of psychological and oxidative stress.

Uran et al. examined Wistar rats that were split into 3 groups: control, acute noise exposure and subacute noise exposure (Urán et al., 2010). Acute noise exposure consisted of loud noise (95-97 dB) for a single 2 hour session, while subacute exposure was the same, but was daily for 15 days. At 30 days, both groups of rats committed more errors on a RAM test, but the rate of learning the task was lower in the subacute group. The subacute group also made 
more errors in an open field test. They also measured oxidative status markers in the hippocampus, specifically brain reactive oxygen species levels and free scavenging antioxidant enzyme activities (catalase and superoxide dismutase) immediately after the last noise exposure. They found acute noise led to a decrease in hippocampal reactive oxygen species, an increase in superoxide dismutase and an increase in catalase and that each of these values trended towards normalizing in the subacute group. The investigators concluded that their findings point to dysregulated hippocampal oxidative stress mechanisms in the generation of learning and memory deficits. In an additional study from the same group male Wistar rats were exposed to noise at 95-97 dB SPL for 2 hours daily either for 1 day in the acute noise exposure group, or between postnatal days 15-30 for the subacute noise exposure group (Urán et al., 2012). They subsequently evaluated the rats' memory in different hippocampal-dependent tasks, such as habituation memory retention in an open-field device, and object recognition device to test recognition memory. They observed that there were significant behavioral abnormalities on the short-term and long-term habituation and object recognition tasks in both exposure groups. They also observed that acute noise exposure increased the number of total (small increase) and pyknotic (large increase) cells in the CA1 and CA3 regions of hippocampus. Subacute exposure increased total cells in CA3 and DG and increased pyknotic cells only in CA3. The generally milder effects on hippocampal pyknosis of subacute exposure compared to acute exposure suggests that some compensation occurs over the multiple days of noise stress.

\subsection{Potential mechanisms linking hearing loss and general cognitive dysfunction}

\subsection{Noise exposure and hippocampal tissue health:}

Multiple potential mechanisms have been proposed to explain how a lesion in the peripheral auditory system can lead to poor performance on non-auditory dependent tasks (Jafari et al., 2019a; Shen et al., 2018). For example, several of the studies described above suggest that noise exposure leads to an increase in oxidative stress in the hippocampus. Oxidative stress reflects a shift in tissue redox state towards oxidation leading to the uncontrolled production of oxygen free radicals and the inability to neutralize them with endogenous antioxidant compounds, such as glutathione. We have previously shown that the hippocampus is particularly prone to hearing lossrelated oxidative stress that is associated with aging, and that hippocampal sensitivity is greater than the auditory cortex (Stebbings et al., 2016a; Stebbings et al., 2016b). This enhanced vulnerability to oxidative stress of the hippocampus compared to auditory structures is consistent with the studies reviewed above by Cheng et al. (Cheng et al., 2011; Cheng et al., 2016) which both showed a drop in the enzyme superoxide dismutase and increase in malondialdehyde in the 
hippocampus to a greater degree than the auditory cortex. The hippocampus may be particularly vulnerable to oxidative stress in general (El Mohsen et al., 2005; Huang et al., 2015), possibly because of the use of reactive oxygen species as a normal part of hippocampal function (Hidalgo et al., 2016). Several studies reviewed above have revealed that noise-induced hearing loss alters markers of oxidative stress in the hippocampus (Cheng et al., 2011; Cheng et al., 2016; Manikandan et al., 2006; Urán et al., 2010) though the mechanism by which hearing loss induces this shift in redox state is not clear. Noise-induced hearing loss causes significant tissue damage to the peripheral hearing apparatus, and may lead to an upregulation of reactive inflammatory changes in the central nervous system (Wang et al., 2019) which may cause a shift in the redox state, leading to hippocampal damage. Psychological stress, as manifested by an increase in plasma corticosterone levels, can also lead to a shift in the brain redox state (Liu et al., 1994; Spiers et al., 2015). Elevated plasma glucocorticoid levels can also independently interfere with hippocampal function (Joëls et al., 2004; Kim et al., 2015). Several studies listed in Table 1 revealed an increase in plasma resting or reactive corticosterone or receptor expression in the hippocampus after noise-exposure (Gai et al., 2017; Hayes et al., 2019; Jáuregui-Huerta et al., 2011; Liu et al., 2016; Manikandan et al., 2006; Shukla et al., 2019), suggesting that psychological stress, either via its effects on hippocampal redox state and/or via direct effects on hippocampal neurons, may have led to hippocampal dysfunction. We do note, however, that mice with agingrelated changes in hearing and never exposed to a loud sound show some similar changes to those seen in noise exposed animals such as increased hippocampal NR2B expression and disrupted spatial memory (Beckmann et al., 2020). This finding argues against noise-induced psychological stress as the only cause of these hippocampal changes.

Related to the findings of elevations in peripheral markers of psychological stress and shift in redox state are the studies showing alterations in the levels of glutamate and NMDA receptor expression in the hippocampus. Elevations of glutamate are known to lead to excitotoxicity, possibly via excessive stimulation of NMDA receptors, and excessive glutamate signaling can lead to a shift in neuronal redox potential (Hasel et al., 2015). Alternatively, a shift in redox potential may lead to an accumulation of extracellular glutamate (Robert et al., 2014). In the studies reviewed above, acute or subacute noise exposure led to an increase in hippocampal glutamate (Cui et al., 2009; Cui et al., 2012). In addition, the acute noise exposure paradigm led to an increase in NR2B expression (Cui et al., 2012), whereas the two subacute exposure studies observed a decrease (Cui et al., 2009; Cui et al., 2013), suggesting that these receptors may be downregulated over time after excessive exposure to glutamate. 
Arguing against the role of noise-induced elevations of cortisol, shift in redox state or excitotoxicity as mechanisms leading to noise-induced hippocampal dysfunction are the time courses of these changes. In most cases when serial measurements have been made after the onset of noise trauma these markers have normalized over time, often despite persistent deficits in assays of learning and memory (Jáuregui-Huerta et al., 2011; Liu et al., 2016; Manikandan et al., 2006; Urán et al., 2010; Urán et al., 2012). These data suggest that an initial burst of excitotoxic activity and/or oxidative stress may trigger longer-lasting hippocampal dysfunction leading to more chronic deficits in learning in memory. To this end, a number of investigators have identified structural changes in the hippocampus that may be responsible for chronic hippocampal dysfunction after noise exposure. One specific change observed across several studies has been the decline in hippocampal neurogenesis after noise exposure (Jáuregui-Huerta et al., 2011; Kraus et al., 2010; Tao et al., 2015). Adult-born hippocampal neurons are thought to be important for learning and memory (Deng et al., 2010; Shors et al., 2001). Hippocampal neurogenesis is also vulnerable to psychological stress (Gould et al., 1999; Schoenfeld et al., 2012), oxidative stress (Huang et al., 2012) as well as excitotoxic stress (Faiz et al., 2005). Thus, it is possible that the diminishment in hippocampal neurogenesis seen after noise exposure is a consequence of the psychological, oxidative and/or excitotoxic stress observed in the hours to days after noise exposure.

In addition to the decline in hippocampal neurogenesis, other long-term structural effects are seen in the hippocampus after noise exposure. For example, noise induced an increase in the number of pyknotic nuclei in the hippocampus (Urán et al., 2012) which is a sign that cells are undergoing either necrosis or apoptosis. Similar findings were seen in Cui et al. (2013). In addition, morphological changes, such as a decrease in hippocampal neuronal dendritic complexity, were also seen after noise exposure (Liu et al., 2018). These effects are likely a consequence of the various forms of acute toxicity described above, and may be responsible for the cognitive deficits which appear to outlast the acutely toxic effects of noise.

An intriguing set of findings with respect to the epidemiological data linking hearing loss to $A D$ are those studies that have identified an increase in phosphorylated tau in the hippocampus after noise exposure (Cheng et al., 2011; Cheng et al., 2016; Cui et al., 2012; Cui et al., 2013; Park et al., 2018). Deposition of hyperphosphorylated tau is a pathological hallmark of $A D$ and the levels of tau deposition are correlate more strongly with cognitive decline in $A D$ than other markers such as amyloid beta deposition (Nelson et al., 2007; Nelson et al., 2012). Tau hyperphosphorylation in Alzheimer Disease is generally felt to occur in the middle or late stages of the pathologic cascade leading to Alzheimer Disease (Hampel et al., 2015; Karran et al., 2011), 
and thus may be a consequence of other toxic or metabolic insults, such as the accumulation of amyloid beta or other molecules. Consistent with this idea is the finding that tau hyperphosphorylation is seen across a number of neurologic diseases (Arendt et al., 2016; Kovacs, 2018), and can be seen in the setting of high stress and glucocorticoid levels (Dey et al., 2017; Rissman et al., 2007), hypothermia (Bretteville et al., 2012; Planel et al., 2007) or diabetes models (Gonçalves et al., 2019; Morales-Corraliza et al., 2016), suggesting that it reflects a response to metabolic stress. In support of the notion that phosphorylation of tau is a consequence of more acute excitotoxic injury to the hippocampus is the finding that systemic exposure to MK-801, an antagonist at the NMDA receptor, inhibits hippocampal tau phosphorylation after noise exposure ( $\mathrm{Li}$ et al., 2014). Thus, the noise-induced increases in hippocampal phosphorylated tau, which are seen at least 12 months post-exposure, are likely caused by the acute injuries to the hippocampus detailed above.

\subsection{Noise exposure and auditory-hippocampal circuitry:}

In addition to the structural lesions to the hippocampus described above, noise exposure may cause circuit-level disruptions in the interactions between the auditory system and the hippocampus. An important question in this context is whether noise-exposure in the studies cited in Table 1 led to significant hearing loss, since the human epidemiological data reviewed above reflect an association between hearing loss, not noise exposure per se, and dementia. Unfortunately, most studies did not measure peripheral hearing function after noise exposure (last column of Table 1). However, those that did observed significant loss of hearing function (generally at least $20 \mathrm{~dB}$ threshold elevations) and the two studies that compared the magnitudes of hearing loss and behavioral metrics of hippocampal function on a per-animal basis found significant correlations between the two (Liu et al., 2016; Tao et al., 2015). These data suggest that loss of auditory input, rather than the stress of noise-exposure only, is a significant driver of hippocampal dysfunction.

It is well-established that hearing loss causes a cascade of changes in the auditory system. For example, noise-induced hearing loss induces increases in spontaneous activity as well as broadening of frequency tuning throughout the central auditory system (Barsz et al., 2007; Jastreboff et al., 1986; Ma et al., 2006; Seki et al., 2002; Seki et al., 2003; Zhang et al., 1998). Other changes are also seen, such as downregulation of synaptic inhibition and increases in burst firing activity (Ibrahim et al., 2019; Mossop et al., 2000; Pilati et al., 2012; Stebbings et al., 2016a; Takesian et al., 2012). It is also known that neurons in the hippocampus respond to acoustic stimuli (Moita et al., 2003; Xiao et al., 2018) and that auditory evoked potentials can be evoked in 
the hippocampus (Bickford-Wimer et al., 1990; Moxon et al., 1999). However, the pathways by which auditory information reaches the hippocampus are not entirely clear. Multiple pathways have been identified. A lemniscal pathway that comprises projections from the auditory cortex to the entorhinal cortex that then projects to the hippocampus has been proposed (Budinger et al., 2009; Germroth et al., 1989; Moxon et al., 1999; Steward, 1976). Additional pathways involving projections from the cochlear nucleus to the brainstem reticular formation and then to the medial septum en route to the hippocampus have also been proposed, as have others involving multimodal cortical areas (Moxon et al., 1999; Munoz-Lopez et al., 2010; Zhang et al., 2018). Finally, acoustic information can travel from either the medial portions of the auditory thalamus (Bordi et al., 1994; LeDoux et al., 1985; Patel et al., 2017) or secondary auditory cortex (Tsukano et al., 2019) to the basolateral amygdala. The basolateral amygdala does not have direct projections to the regions of the dorsal hippocampus that are important for the spatial memory tasks outlined above, but projects to the medial entorhinal cortex, which may then influence hippocampal spatial memory (Wahlstrom et al., 2018), see Figure 4 for a summary of potential pathways. Given the alteration in spontaneous and driven spiking properties of auditory system neurons that ultimately project to the hippocampus, it is likely that hippocampal function is perturbed after noise exposure, independently of the hippocampal tissue toxicity mechanisms described above. However, we are not aware of any studies, outside of Goble et al. 2009 that have examined the electrophysiological properties of hippocampal neurons after hearing loss.

It is also possible that noise may cause functional alterations by altering thalamocortical rhythms associated with sleep. For example, Rabat et al. examined the effects of chronic exposure of environmental noise on long-term memory and linked these behavioral problems to sleep disturbances related to environmental noise in rats (Rabat et al., 2006). The long-term memory performance was evaluated using a novel spatial exploration assay, before and 9 days following environmental noise exposure. The investigators also evaluated the effect of noiseexposure on sleep disturbance by using EEG recordings with surgically implanted electrodes. The investigators observed deficits after the chronic environmental noise exposure with interindividual vulnerability that was determined based on the animal's response to novelty. They found that the long-term memory deficits correlated to both a loss of slow wave sleep and slow wave sleep bout duration, suggesting that a potential mechanism of noise effects on general cognition is via disruption of slow-wave sleep. It is also possible that sleep disruption is simply a marker for psychological stress and glucocorticoid increases, which may be the real mediator. Further studies here are necessary. 


\subsection{Conclusions and open questions:}

Here, we have described a likely cascade of events that leads to hippocampal dysfunction after noise exposure and hearing loss. Noise exposure itself is a destructive force and the process of being noise-exposed likely produces substantial psychological stress. Therefore, in the early period (hours) after noise exposure, there is likely a toxic milieu that is induced that includes central nervous system inflammation, high levels of circulating glucocorticoids, an oxidative shift in hippocampal neuronal redox state and excitotoxic elevations of hippocampal glutamate. As a consequence of this toxic milieu, hippocampal neurogenesis is downregulated, neuronal tau proteins become hyperphosphorylated and a sub-population of hippocampal neurons undergo apoptosis, leading to poor performance on hippocampal-based memory tasks (Figure 5).

Although this proposed sequence of events may help explain some of the rodent behavioral data showing that noise exposure causes hippocampal dysfunction, many questions remain. For example, it is not at all clear whether the key factor that incites plastic changes in the hippocampus is the noise trauma itself, and the related tissue destruction within the cochlea (and/or the psychological trauma from the noise exposure) or the sensory deprivation that occurs as a consequence of the trauma. In the epidemiological link between hearing loss and $A D$, in most cases there is no trauma - only a gradual loss of peripheral auditory function related to aging. Indirect evidence suggestive that sensory deprivation is a key factor is the finding that an intervention that protected hair cells and peripheral hearing (the adenosine $A_{2 A}$ agonist CGS21680), also protected the hippocampus from noise damage (Shukla et al., 2019). Other studies that are suggestive of an independent role of hearing loss are those that showed a correlation between the degree of hearing loss and the degree of behavioral impairment (Liu et al., 2016; Tao et al., 2015). Of course, these studies are also confounded because the degree of hearing loss is related to the degree of cochlear tissue destruction. What will be necessary to answer the question of noise-related tissue destruction vs. sensory deprivation is to nondestructively induce auditory deprivation such as with the use of ear plugs (Caras et al., 2015; Mowery et al., 2015) and then examine performance on non-auditory dependent behavioral tasks.

Another limitation in the ability to extrapolate the above-reviewed studies to the potential connection between hearing loss and $A D$ is that the vast majority of studies established a relatively short term relationship (hours to weeks) that generally showed improvement over time. That is, most subjects showed gradual recovery in their non-auditory memory function. The few studies that examined long-term effects (up to 12 months) also showed partial recovery, but also used aggressive means to lesion the hearing apparatus ( $110 \mathrm{~dB}$ SPL noise for 60 min day $\times 20$ days (Park et al., 2016; Park et al., 2018)). None of the studies reviewed above showed that 
hearing loss induced a progressive cognitive syndrome akin to a neurodegenerative process. Thus, it may be that hearing loss on its own may not be enough to induce a progressive neurodegenerative syndrome. That is, a second "hit" may be necessary, such as noise exposure to an aging animal or an animal engineered to express mutant human apolipoprotein or overproduce amyloid beta or to hyperphosphorylate tau. To that end, a useful approach may be to induce hearing loss in a mouse engineered to have one "hit" (e.g., overexpression of amyloid beta or tau) and to induce a hearing loss (the second "hit") and to examine long-term consequences in terms of cognition. Over the past 25 years, there have been dozens of mouse models of AD that have been introduced to the literature. Early models only expressed single mutated genes that produce amyloid beta (Games et al., 1995; Hsiao et al., 1996), while later models were engineered to overproduce amyloid beta and tau (Oakley et al., 2006; Oddo et al., 2003), while several other models do not contain mutations that directly influence amyloid beta or tau, but may lead to their deposition (Lester-Coll et al., 2006; Park et al., 2007) as well as other models that have mutations for combinations of risk factors for both sporadic and familial AD (Holtzman et al., 2000; Youmans et al., 2012). Unfortunately, very little work has yet been done to examine the impact of hearing loss in these animals from the perspective of accelerating a neurodegenerative phenotype. Recent work has been done to show that either prenatal noise exposure (Jafari et al., 2019b; Jafari et al., 2019c) or adult cochlear ablation in the setting of excess amyloid-beta (Chang et al., 2019) appear to worsen AD-related and hippocampal pathology. None of these studies, however, established that a progressive degenerative disorder was induced by hearing loss. Finally, most (19 out of 24 ) of the studies reviewed above were done in males. Given the female predominance for risk of cognitive decline in AD (Buckley et al., 2018; Fisher et al., 2018; Podcasy et al., 2016), and the male predominance of ARHL (Hong et al., 2015; Raynor et al., 2009; Roth et al., 2011), it will be important to know if sex plays a role in the likelihood of hearing loss leading to hippocampal dysfunction. Therefore, additional studies in older animals and/or disease models, in male and female animals, and/or use of a less destructive means to diminish hearing, will be useful to understand the interactions between noise exposure, auditory deprivation and preexisting pathology that potentially lead to AD.

\section{Figure Legends:}

Figure 1: Kaplan-Meier curve illustrating the likelihood of developing dementia in elderly men without a previous diagnosis of dementia that either had normal hearing (blue line) or had hearing loss (based on diagnosis codes, brown line) at study entry. Rates of development of dementia were adjusted for age and aging-associated comorbidities such as cardiac disease, respiratory 
disease, gastrointestinal or kidney disease as well as cancer. The adjusted Hazard Ratio for developing dementia was 1.69. Data obtained with permission from (Ford et al., 2018).

Figure 2: Example of heatmaps of place cell activity overlaid with the rodent's behavioral path (thin black line) and single unit firing of place cells (black squares) before (left) and 2, 4 and 6 hours after noise exposure (4 kHz tone at $104 \mathrm{~dB}$ SPL for $30 \mathrm{~min}$ ). Note that novel place fields arose at sites $A$ and $B$ after noise exposure. Reproduced with permission from (Goble et al., 2009).

Figure 3: Density analysis taken from Western blots of hippocampal tissue probed with an antibody against the phosphorylation site at Serine 396 of tau. Levels were normalized to the tau levels in the control group and done with three replicates. Error bars represent the standard deviation. ${ }^{* *} \mathrm{p}<0.001$ compared to control. Reproduced with permission from (Cheng et al., 2016).

Figure 4: Diagram of potential pathways by which sound (or the absence of sound) can influence the hippocampus. A canonical pathway exists that takes information from the inner hair cell, through the traditional ascending auditory pathway to the auditory cortex, then reaches hippocampus via entorhinal cortex (red). Two alternatives involve either the amygdala or nonauditory heteromodal cortex (pink). A non-canonical pathway, sometimes referred to as a "reticulo-limbic" pathway is shown in green.

Figure 5: Proposed sequence of events that leads to hippocampal dysfunction after noise exposure. Noise exposure leads to an acute increase in circulating glucocorticoids and increases in hippocampal oxidative and excitotoxic stress. These changes led to a decrease in hippocampal neurogenesis, diminished synaptic connectivity within the hippocampus and increased tau phosphorylation and the associated diminished performance in hippocampal-based tests such as the MWM and RAM.

\section{Citations:}

Arendt, T., Stieler, J.T., Holzer, M. 2016. Tau and tauopathies. Brain research bulletin 126, 238292. 
Barnes, J., Bartlett, J.W., van de Pol, L.A., Loy, C.T., Scahill, R.I., Frost, C., Thompson, P., Fox, N.C. 2009. A meta-analysis of hippocampal atrophy rates in Alzheimer's disease. Neurobiology of aging 30, 1711-1723.

Barsz, K., Wilson, W.W., Walton, J.P. 2007. Reorganization of receptive fields following hearing loss in inferior colliculus neurons. Neuroscience 147, 532-545.

Beckmann, D., Feldmann, M., Shchyglo, O., Manahan-Vaughan, D. 2020. Hippocampal Synaptic Plasticity, Spatial Memory, and Neurotransmitter Receptor Expression Are Profoundly Altered by Gradual Loss of Hearing Ability. Cerebral Cortex.

Bickford-Wimer, P.C., Nagamoto, H., Johnson, R., Adler, L.E., Egan, M., Rose, G.M., Freedman, R. 1990. Auditory sensory gating in hippocampal neurons: a model system in the rat. Biological psychiatry 27, 183-192.

Bordi, F., LeDoux, J.E. 1994. Response properties of single units in areas of rat auditory thalamus that project to the amygdala II. Cells receiving convergent auditory and somatosensory inputs and cells antidromically activated by amygdala Experimental Brain Research 98, 275-286.

Bretteville, A., Marcouiller, F., Julien, C., El Khoury, N.B., Petry, F.R., Poitras, I., Mouginot, D., Lévesque, G., Hébert, S.S., Planel, E. 2012. Hypothermia-induced hyperphosphorylation: a new model to study tau kinase inhibitors. Scientific reports 2, 480.

Buckley, R.F., Mormino, E.C., Amariglio, R.E., Properzi, M.J., Rabin, J.S., Lim, Y.Y., Papp, K.V., Jacobs, H.I., Burnham, S., Hanseeuw, B.J. 2018. Sex, amyloid, and APOE $\varepsilon 4$ and risk of cognitive decline in preclinical Alzheimer's disease: findings from three well-characterized cohorts. Alzheimer's \& Dementia 14, 1193-1203.

Budinger, E., Scheich, H. 2009. Anatomical connections suitable for the direct processing of neuronal information of different modalities via the rodent primary auditory cortex. Hearing research 258, 16-27.

Caras, M.L., Sanes, D.H. 2015. Sustained perceptual deficits from transient sensory deprivation. Journal of Neuroscience 35, 10831-10842.

Chang, M., Kim, H.J., Mook-Jung, I., Oh, S.-h. 2019. Hearing loss as a risk factor for cognitive impairment and loss of synapses in the hippocampus. Behavioural brain research 372 , 112069.

Chen, S.P., Bhattacharya, J., Pershing, S. 2017. Association of vision loss with cognition in older adults. JAMA ophthalmology 135, 963-970.

Cheng, L., Wang, S.-H., Chen, Q.-C., Liao, X.-M. 2011. Moderate noise induced cognition impairment of mice and its underlying mechanisms. Physiology \& behavior 104, 981-988.

Cheng, L., Wang, S.-H., Huang, Y., Liao, X.-M. 2016. The hippocampus may be more susceptible to environmental noise than the auditory cortex. Hearing research 333, 93-97.

Chengzhi, C., Yan, T., Xuejun, J., Xiang, L., Youbin, Q., Baijie, T. 2011. Recovery of chronic noise exposure induced spatial learning and memory deficits in young male Sprague-Dawley rats. Journal of occupational health, 1103110178-1103110178.

Chien, W., Lin, F.R. 2012. Prevalence of hearing aid use among older adults in the United States. Archives of internal medicine 172, 292-293.

Cui, B., Wu, M., She, X. 2009. Effects of chronic noise exposure on spatial learning and memory of rats in relation to neurotransmitters and NMDAR2B alteration in the hippocampus. Journal of occupational health, 0902160059-0902160059.

Cui, B., Wu, M., She, X., Liu, H. 2012. Impulse noise exposure in rats causes cognitive deficits and changes in hippocampal neurotransmitter signaling and tau phosphorylation. Brain research 1427, 35-43.

Cui, B., Wu, M.Q., Zhu, L.X., She, X.J., Ma, Q., Liu, H.T. 2013. Effect of chronic noise exposure on expression of $\mathrm{N}$-methyl-D-aspartic acid receptor 2B and Tau phosphorylation in hippocampus of rats. Biomed Environ Sci 26, 163-168. 
De Deus, J., Cunha, A., Terzian, A., Resstel, L., Elias, L.L.K., Antunes-Rodrigues, J., Almeida, S.d.S., Leão, R. 2017. A single episode of high intensity sound inhibits long-term potentiation in the hippocampus of rats. Scientific reports 7, 1-13.

Deng, W., Aimone, J.B., Gage, F.H. 2010. New neurons and new memories: how does adult hippocampal neurogenesis affect learning and memory? Nature reviews neuroscience 11, 339-350.

Dey, A., Hao, S., Wosiski-Kuhn, M., Stranahan, A.M. 2017. Glucocorticoid-mediated activation of GSK3 $\beta$ promotes tau phosphorylation and impairs memory in type 2 diabetes. Neurobiology of aging 57, 75-83.

El Mohsen, M.M.A., Iravani, M.M., Spencer, J.P., Rose, S., Fahim, A.T., Motawi, T.M., Ismail, N.A., Jenner, P. 2005. Age-associated changes in protein oxidation and proteasome activities in rat brain: modulation by antioxidants. Biochemical and biophysical research communications 336, 386-391.

Faiz, M., Acarin, L., Castellano, B., Gonzalez, B. 2005. Proliferation dynamics of germinative zone cells in the intact and excitotoxically lesioned postnatal rat brain. BMC neuroscience 6, 26.

Fisher, D.W., Bennett, D.A., Dong, H. 2018. Sexual dimorphism in predisposition to Alzheimer's disease. Neurobiology of aging 70, 308-324.

Ford, A.H., Hankey, G.J., Yeap, B.B., Golledge, J., Flicker, L., Almeida, O.P. 2018. Hearing loss and the risk of dementia in later life. Maturitas 112, 1-11.

Gai, Z., Su, D., Wang, Y., Li, W., Cui, B., Li, K., She, X., Wang, R. 2017. Effects of chronic noise on the corticotropin-releasing factor system in the rat hippocampus: relevance to Alzheimer's disease-like tau hyperphosphorylation. Environmental health and preventive medicine 22, 79.

Games, D., Adams, D., Alessandrini, R., Barbour, R., Borthelette, P., Blackwell, C., Carr, T., Clemens, J., Donaldson, T., Gillespie, F. 1995. Alzheimer-type neuropathology in transgenic mice overexpressing V717F $\beta$-amyloid precursor protein. Nature 373, 523-527.

Germroth, P., Schwerdtfeger, W., Buhl, E. 1989. Morphology of identified entorhinal neurons projecting to the hippocampus. A light microscopical study combining retrograde tracing and intracellular injection. Neuroscience 30, 683-691.

Goble, T., Møller, A., Thompson, L. 2009. Acute high-intensity sound exposure alters responses of place cells in hippocampus. Hearing research 253, 52-59.

Golub, J.S., Luchsinger, J.A., Manly, J.J., Stern, Y., Mayeux, R., Schupf, N. 2017. Observed hearing loss and incident dementia in a multiethnic cohort. J. Am. Geriatr. Soc. 65, 16911697.

Gonçalves, R.A., Wijesekara, N., Fraser, P.E., De Felice, F.G. 2019. The link between tau and insulin signaling: implications for Alzheimer's disease and other tauopathies. Frontiers in cellular neuroscience 13, 17.

Gould, E., Tanapat, P. 1999. Stress and hippocampal neurogenesis. Biological psychiatry 46, 1472-1479.

Gurgel, R.K., Ward, P.D., Schwartz, S., Norton, M.C., Foster, N.L., Tschanz, J.T. 2014. Relationship of hearing loss and dementia: a prospective, population-based study. Otology \& neurotology: official publication of the American Otological Society, American Neurotology Society [and] European Academy of Otology and Neurotology 35, 775.

Haider, S., Naqvi, F., Batool, Z., Tabassum, S., Perveen, T., Saleem, S., Haleem, D.J. 2012. Decreased hippocampal 5-HT and DA levels following sub-chronic exposure to noise stress: impairment in both spatial and recognition memory in male rats. Scientia pharmaceutica 80, 1001-1012.

Hampel, H., Schneider, L.S., Giacobini, E., Kivipelto, M., Sindi, S., Dubois, B., Broich, K., Nistico, R., Aisen, P.S., Lista, S. 2015. Advances in the therapy of Alzheimer's disease: targeting amyloid beta and tau and perspectives for the future. Expert review of neurotherapeutics 15, 83-105. 
Hasel, P., Mckay, S., Qu, J., Hardingham, G.E. 2015. Selective dendritic susceptibility to bioenergetic, excitotoxic and redox perturbations in cortical neurons. Biochimica et Biophysica Acta (BBA)-Molecular Cell Research 1853, 2066-2076.

Hayes, S.H., Manohar, S., Majumdar, A., Allman, B.L., Salvi, R. 2019. Noise-induced hearing loss alters hippocampal glucocorticoid receptor expression in rats. Hearing research $379,43-$ 51.

Heywood, R., Gao, Q., Nyunt, M.S.Z., Feng, L., Chong, M.S., Lim, W.S., Yap, P., Lee, T.-S., Yap, K.B., Wee, S.L. 2017. Hearing loss and risk of mild cognitive impairment and dementia: findings from the Singapore longitudinal ageing study. Dementia and geriatric cognitive disorders 43, 259-268.

Hidalgo, C., Arias-Cavieres, A. 2016. Calcium, reactive oxygen species, and synaptic plasticity. Physiology 31, 201-215.

Holtzman, D.M., Bales, K.R., Tenkova, T., Fagan, A.M., Parsadanian, M., Sartorius, L.J., Mackey, B., Olney, J., McKeel, D., Wozniak, D. 2000. Apolipoprotein E isoform-dependent amyloid deposition and neuritic degeneration in a mouse model of Alzheimer's disease. Proceedings of the National Academy of Sciences 97, 2892-2897.

Hong, J.W., Jeon, J.H., Ku, C.R., Noh, J.H., Yoo, H.J., Kim, D.-J. 2015. The prevalence and factors associated with hearing impairment in the Korean adults: the 2010-2012 Korea National Health and Nutrition Examination Survey (observational study). Medicine 94.

Hsiao, K., Chapman, P., Nilsen, S., Eckman, C., Harigaya, Y., Younkin, S., Yang, F., Cole, G. 1996. Correlative memory deficits, $A \beta$ elevation, and amyloid plaques in transgenic mice. Science 274, 99-103.

Huang, T.-T., Zou, Y., Corniola, R. 2012. Oxidative stress and adult neurogenesis-effects of radiation and superoxide dismutase deficiency, Seminars in cell \& developmental biology, Vol. 23. Elsevier. pp. 738-744.

Huang, T.-T., Leu, D., Zou, Y. 2015. Oxidative stress and redox regulation on hippocampaldependent cognitive functions. Archives of biochemistry and biophysics 576, 2-7.

Ibrahim, B.A., Llano, D.A. 2019. Aging and Central Auditory Disinhibition: Is It a Reflection of Homeostatic Downregulation or Metabolic Vulnerability? Brain Sciences 9, 351.

Jafari, Z., Kolb, B.E., Mohajerani, M.H. 2019a. Noise exposure accelerates the risk of cognitive impairment and Alzheimer's disease: Adulthood, gestational, and prenatal mechanistic evidence from animal studies. Neuroscience \& Biobehavioral Reviews.

Jafari, Z., Mehla, J., Kolb, B.E., Mohajerani, M.H. 2019b. Gestational Stress Augments Postpartum $\beta$-Amyloid Pathology and Cognitive Decline in a Mouse Model of Alzheimer's Disease. Cerebral Cortex 29, 3712-3724.

Jafari, Z., Okuma, M., Karem, H., Mehla, J., Kolb, B.E., Mohajerani, M.H. 2019c. Prenatal noise stress aggravates cognitive decline and the onset and progression of beta amyloid pathology in a mouse model of Alzheimer's disease. Neurobiology of aging 77, 66-86.

Jastreboff, P.J., Sasaki, C.T. 1986. Salicylate-induced changes in spontaneous activity of single units in the inferior colliculus of the guinea pig. The Journal of the Acoustical Society of America 80, 1384-1391.

Jáuregui-Huerta, F., García-Estrada, J., Ruvalcaba-Delgadillo, Y., Trujillo, X., Huerta, M., FeriaVelasco, A., Gonzalez-Perez, O., Luquín, S. 2011. Chronic exposure of juvenile rats to environmental noise impairs hippocampal cell proliferation in adulthood. Noise and Health 13, 286.

Joëls, M., Karst, H., Alfarez, D., Heine, V.M., Qin, Y., Riel, E.v., Verkuyl, M., Lucassen, P.J., Krugers, H.J. 2004. Effects of chronic stress on structure and cell function in rat hippocampus and hypothalamus. Stress 7, 221-231.

Karran, E., Mercken, M., De Strooper, B. 2011. The amyloid cascade hypothesis for Alzheimer's disease: an appraisal for the development of therapeutics. Nature reviews Drug discovery 10, 698-712. 
Kim, E.J., Pellman, B., Kim, J.J. 2015. Stress effects on the hippocampus: a critical review. Learning \& memory 22, 411-416.

Kimura, M., Eggermont, J.J. 1999. Effects of acute pure tone induced hearing loss on response properties in three auditory cortical fields in cat. Hearing research 135, 146-162.

Kovacs, G.G. 2018. Tauopathies, Handbook of clinical neurology, Vol. 145. Elsevier. pp. 355-368.

Kraus, K.S., Mitra, S., Jimenez, Z., Hinduja, S., Ding, D., Jiang, H., Gray, L., Lobarinas, E., Sun, W., Salvi, R.J. 2010. Noise trauma impairs neurogenesis in the rat hippocampus. Neuroscience 167, 1216-1226.

LeDoux, J.E., Ruggiero, D.A., Reis, D. 1985. Projections to the subcortical forebrain from anatomically defined regions of the medial geniculate body in the rat. Journal of Comparative Neurology 242, 182-213.

Lester-Coll, N., Rivera, E.J., Soscia, S.J., Doiron, K., Wands, J.R., de la Monte, S.M. 2006. Intracerebral streptozotocin model of type 3 diabetes: relevance to sporadic Alzheimer's disease. Journal of Alzheimer's Disease 9, 13-33.

Li, K., Jia, H., She, X., Cui, B., Zhang, N., Chen, X., Xu, C., An, G., Ma, Q. 2014. Role of NMDA receptors in noise-induced tau hyperphosphorylation in rat hippocampus and prefrontal cortex. Journal of the neurological sciences 340, 191-197.

Lin, F.R., Metter, E.J., O’Brien, R.J., Resnick, S.M., Zonderman, A.B., Ferrucci, L. 2011a. Hearing loss and incident dementia. Archives of neurology 68, 214-220.

Lin, F.R., Ferrucci, L., Metter, E.J., An, Y., Zonderman, A.B., Resnick, S.M. 2011b. Hearing loss and cognition in the Baltimore Longitudinal Study of Aging. Neuropsychology 25, 763.

Lin, F.R., Yaffe, K., Xia, J., Xue, Q.-L., Harris, T.B., Purchase-Helzner, E., Satterfield, S., Ayonayon, H.N., Ferrucci, L., Simonsick, E.M. 2013. Hearing loss and cognitive decline in older adults. JAMA internal medicine 173, 293-299.

Lin, I.-C., Wang, Y.-H., Wang, T.-J., Wang, I.-J., Shen, Y.-D., Chi, N.-F., Chien, L.-N. 2014. Glaucoma, Alzheimer's disease, and Parkinson's disease: an 8-year population-based follow-up study. PloS one 9.

Liu, J., Mori, A. 1994. Involvement of reactive oxygen species in emotional stress: a hypothesis based on the immobilization stress-induced oxidative damage and antioxidant defense changes in rat brain, and the effect of antioxidant treatment with reduced glutathione. International Journal of Stress Management 1, 249-263.

Liu, L., Shen, P., He, T., Chang, Y., Shi, L., Tao, S., Li, X., Xun, Q., Guo, X., Yu, Z. 2016. Noise induced hearing loss impairs spatial learning/memory and hippocampal neurogenesis in mice. Scientific reports 6, 20374.

Liu, L., Xuan, C., Shen, P., He, T., Chang, Y., Shi, L., Tao, S., Yu, Z., Brown, R.E., Wang, J. 2018. Hippocampal Mechanisms Underlying Impairment in Spatial Learning Long After Establishment of Noise-Induced Hearing Loss in CBA Mice. Frontiers in systems neuroscience 12, 35.

Ma, W.-L.D., Hidaka, H., May, B.J. 2006. Spontaneous activity in the inferior colliculus of CBA/J mice after manipulations that induce tinnitus. Hearing research 212, 9-21.

Mangione, C.M., Seddon, J.M., Cook, E.F., Krug Jr, J.H., Sahagian, C.R., Campion, E.W., Glynn, R.J. 1993. Correlates of cognitive function scores in elderly outpatients. Journal of the American Geriatrics society 41, 491-497.

Manikandan, S., Padma, M.K., Srikumar, R., Parthasarathy, N.J., Muthuvel, A., Devi, R.S. 2006. Effects of chronic noise stress on spatial memory of rats in relation to neuronal dendritic alteration and free radical-imbalance in hippocampus and medial prefrontal cortex. Neuroscience letters 399, 17-22.

Mann, D., Yates, P. 1974. Lipoprotein pigments-their relationship to ageing in the human nervous system: I. The lipofuscin content of nerve cells. Brain 97, 481-488.

McKinnon, S.J. 2003. Glaucoma: ocular Alzheimer's disease. Front biosci 8, s1140-56. 
Moita, M.A., Rosis, S., Zhou, Y., LeDoux, J.E., Blair, H.T. 2003. Hippocampal place cells acquire location-specific responses to the conditioned stimulus during auditory fear conditioning. Neuron 37, 485-497.

Morales-Corraliza, J., Wong, H., Mazzella, M.J., Che, S., Lee, S.H., Petkova, E., Wagner, J.D., Hemby, S.E., Ginsberg, S.D., Mathews, P.M. 2016. Brain-wide insulin resistance, tau phosphorylation changes, and hippocampal neprilysin and amyloid- $\beta$ alterations in a monkey model of type 1 diabetes. Journal of Neuroscience 36, 4248-4258.

Moreno-García, A., Kun, A., Calero, O., Medina, M., Calero, M. 2018. An overview of the role of lipofuscin in age-related neurodegeneration. Frontiers in Neuroscience 12, 464.

Mossop, J., Wilson, M., Caspary, D., Moore, D. 2000. Down-regulation of inhibition following unilateral deafening. Hearing research 147, 183-187.

Mowery, T.M., Kotak, V.C., Sanes, D.H. 2015. Transient hearing loss within a critical period causes persistent changes to cellular properties in adult auditory cortex. Cerebral cortex 25, 2083-2094.

Moxon, K.A., Gerhardt, G.A., Bickford, P.C., Austin, K., Rose, G.M., Woodward, D.J., Adler, L.E. 1999. Multiple single units and population responses during inhibitory gating of hippocampal auditory response in freely-moving rats. Brain research 825, 75-85.

Mullins, R.F., Russell, S.R., Anderson, D.H., Hageman, G.S. 2000. Drusen associated with aging and age-related macular degeneration contain proteins common to extracellular deposits associated with atherosclerosis, elastosis, amyloidosis, and dense deposit disease. The FASEB Journal 14, 835-846.

Munoz-Lopez, M., MohedanoMoriano, A., Insausti, R. 2010. Anatomical pathways for auditory memory in primates. Frontiers in neuroanatomy 4, 129.

Nelson, P.T., Jicha, G.A., Schmitt, F.A., Liu, H., Davis, D.G., Mendiondo, M.S., Abner, E.L., Markesbery, W.R. 2007. Clinicopathologic correlations in a large Alzheimer disease center autopsy cohort: neuritic plaques and neurofibrillary tangles" do count" when staging disease severity. Journal of Neuropathology \& Experimental Neurology 66, 1136-1146.

Nelson, P.T., Alafuzoff, I., Bigio, E.H., Bouras, C., Braak, H., Cairns, N.J., Castellani, R.J., Crain, B.J., Davies, P., Tredici, K.D. 2012. Correlation of Alzheimer disease neuropathologic changes with cognitive status: a review of the literature. Journal of Neuropathology \& Experimental Neurology 71, 362-381.

Norena, A.J., Tomita, M., Eggermont, J.J. 2003. Neural changes in cat auditory cortex after a transient pure-tone trauma. Journal of Neurophysiology 90, 2387-2401.

O'Leary, T., Shin, S., Fertan, E., Dingle, R., Almuklass, A., Gunn, R., Yu, Z., Wang, J., Brown, R. 2017. Reduced acoustic startle response and peripheral hearing loss in the 5xFAD mouse model of Alzheimer's disease. Genes, Brain and Behavior 16, 554-563.

Oakley, H., Cole, S.L., Logan, S., Maus, E., Shao, P., Craft, J., Guillozet-Bongaarts, A., Ohno, M., Disterhoft, J., Van Eldik, L. 2006. Intraneuronal $\beta$-amyloid aggregates, neurodegeneration, and neuron loss in transgenic mice with five familial Alzheimer's disease mutations: potential factors in amyloid plaque formation. Journal of Neuroscience 26, 10129-10140.

Oddo, S., Caccamo, A., Kitazawa, M., Tseng, B.P., LaFerla, F.M. 2003. Amyloid deposition precedes tangle formation in a triple transgenic model of Alzheimer's disease. Neurobiology of aging 24, 1063-1070.

Park, K.H., Hallows, J.L., Chakrabarty, P., Davies, P., Vincent, I. 2007. Conditional neuronal simian virus $40 \mathrm{~T}$ antigen expression induces Alzheimer-like tau and amyloid pathology in mice. Journal of Neuroscience 27, 2969-2978.

Park, S.Y., Kim, M.J., Sikandaner, H., Kim, D.-K., Yeo, S.W., Park, S.N. 2016. A causal relationship between hearing loss and cognitive impairment. Acta oto-laryngologica 136, 480-483. 
Park, S.Y., Kim, M.J., Kim, H.L., Kim, D.K., Yeo, S.W., Park, S.N. 2018. Cognitive decline and increased hippocampal p-tau expression in mice with hearing loss. Behavioural brain research 342, 19-26.

Patel, M., Sons, S., Yudintsev, G., Lesicko, A.M., Yang, L., Taha, G., Pierce, S., Llano, D. 2017. Anatomical characterization of subcortical descending projections to the inferior colliculus in mouse. Journal of Comparative Neurology Mar 1;525, 885-900.

Pilati, N., Large, C., Forsythe, I.D., Hamann, M. 2012. Acoustic over-exposure triggers burst firing in dorsal cochlear nucleus fusiform cells. Hearing research 283, 98-106.

Planel, E., Richter, K.E., Nolan, C.E., Finley, J.E., Liu, L., Wen, Y., Krishnamurthy, P., Herman, M., Wang, L., Schachter, J.B. 2007. Anesthesia leads to tau hyperphosphorylation through inhibition of phosphatase activity by hypothermia. Journal of Neuroscience 27, 3090-3097.

Podcasy, J.L., Epperson, C.N. 2016. Considering sex and gender in Alzheimer disease and other dementias. Dialogues in clinical neuroscience 18, 437.

Popelka, M.M., Cruickshanks, K.J., Wiley, T.L., Tweed, T.S., Klein, B.E., Klein, R. 1998. Low prevalence of hearing aid use among older adults with hearing loss: the Epidemiology of Hearing Loss Study. Journal of the American Geriatrics Society 46, 1075-1078.

Rabat, A., Bouyer, J., George, O., Le Moal, M., Mayo, W. 2006. Chronic exposure of rats to noise: relationship between long-term memory deficits and slow wave sleep disturbances. Behavioural brain research 171, 303-312.

Raynor, L.A., Pankow, J.S., Miller, M.B., Huang, G.-H., Dalton, D., Klein, R., Klein, B.E., Cruickshanks, K.J. 2009. Familial aggregation of age-related hearing loss in an epidemiological study of older adults. American journal of audiology.

Rissman, R.A., Lee, K.-F., Vale, W., Sawchenko, P.E. 2007. Corticotropin-releasing factor receptors differentially regulate stress-induced tau phosphorylation. Journal of Neuroscience 27, 6552-6562.

Robert, S.M., Ogunrinu-Babarinde, T., Holt, K.T., Sontheimer, H. 2014. Role of glutamate transporters in redox homeostasis of the brain. Neurochemistry international 73, 181-191.

Roth, T.N., Hanebuth, D., Probst, R. 2011. Prevalence of age-related hearing loss in Europe: a review. European Archives of Oto-Rhino-Laryngology 268, 1101-1107.

Scheff, S., Price, D., Schmitt, F., DeKosky, S., Mufson, E. 2007. Synaptic alterations in CA1 in mild Alzheimer disease and mild cognitive impairment. Neurology 68, 1501-1508.

Schoenfeld, T.J., Gould, E. 2012. Stress, stress hormones, and adult neurogenesis. Experimental neurology 233, 12-21.

Seki, S., Eggermont, J.J. 2002. Changes in cat primary auditory cortex after minor-to-moderate pure-tone induced hearing loss. Hearing research 173, 172-186.

Seki, S., Eggermont, J.J. 2003. Changes in spontaneous firing rate and neural synchrony in cat primary auditory cortex after localized tone-induced hearing loss. Hearing research 180, 28-38.

Shen, Y., Ye, B., Chen, P., Wang, Q., Fan, C., Shu, Y., Xiang, M. 2018. Cognitive decline, dementia, alzheimer's disease and presbycusis: examination of the possible molecular mechanism. Frontiers in neuroscience 12, 394.

Shors, T.J., Miesegaes, G., Beylin, A., Zhao, M., Rydel, T., Gould, E. 2001. Neurogenesis in the adult is involved in the formation of trace memories. Nature 410, 372-376.

Shukla, M., Roy, K., Kaur, C., Nayak, D., Mani, K., Shukla, S., Kapoor, N. 2019. Attenuation of adverse effects of noise induced hearing loss on adult neurogenesis and memory in rats by intervention with Adenosine A2A receptor agonist. Brain research bulletin 147, 47-57.

Spiers, J.G., Chen, H.-J.C., Sernia, C., Lavidis, N.A. 2015. Activation of the hypothalamicpituitary-adrenal stress axis induces cellular oxidative stress. Frontiers in neuroscience 8 , 456. 
Stebbings, K., Choi, H., Ravindra, A., Caspary, D., Turner, J., Llano, D. 2016a. Ageing-related changes in GABAergic inhibition in mouse auditory cortex, measured using in vitro flavoprotein autofluorescence imaging. The Journal of Physiology 594, 207-221.

Stebbings, K.A., Choi, H.W., Ravindra, A., Llano, D.A. 2016b. The impact of aging, hearing loss, and body weight on mouse hippocampal redox state, measured in brain slices using fluorescence imaging. Neurobiology of Aging 42, 101-109.

Steward, O. 1976. Topographic organization of the projections from the entorhinal area to the hippocampal formation of the rat. Journal of Comparative Neurology 167, 285-314.

Swords, G.M., Nguyen, L.T., Mudar, R.A., Llano, D.A. 2018. Auditory system dysfunction in Alzheimer disease and its prodromal states: A review. Ageing research reviews.

Takesian, A.E., Kotak, V.C., Sanes, D.H. 2012. Age-dependent effect of hearing loss on cortical inhibitory synapse function. Journal of neurophysiology 107, 937-947.

Tao, S., Liu, L., Shi, L., Li, X., Shen, P., Xun, Q., Guo, X., Yu, Z., Wang, J. 2015. Spatial learning and memory deficits in young adult mice exposed to a brief intense noise at postnatal age. Journal of otology 10, 21-28.

Thomson, R.S., Auduong, P., Miller, A.T., Gurgel, R.K. 2017. Hearing loss as a risk factor for dementia: a systematic review. Laryngoscope investigative otolaryngology 2, 69-79.

Tromp, D., Dufour, A., Lithfous, S., Pebayle, T., Després, O. 2015. Episodic memory in normal aging and Alzheimer disease: insights from imaging and behavioral studies. Ageing research reviews 24, 232-262.

Tsukano, H., Hou, X., Horie, M., Kitaura, H., Nishio, N., Hishida, R., Takahashi, K., Kakita, A., Takebayashi, H., Sugiyama, S. 2019. Reciprocal connectivity between secondary auditory cortical field and amygdala in mice. Scientific Reports 9.

Urán, S.L., Cáceres, L.G., Guelman, L.R. 2010. Effects of loud noise on hippocampal and cerebellar-related behaviors.: Role of oxidative state. Brain research 1361, 102-114.

Urán, S.L., Aon-Bertolino, M.L., Cáceres, L.G., Capani, F., Guelman, L.R. 2012. Rat hippocampal alterations could underlie behavioral abnormalities induced by exposure to moderate noise levels. Brain research 1471, 1-12.

Wahlstrom, K.L., Huff, M.L., Emmons, E.B., Freeman, J.H., Narayanan, N.S., Mclntyre, C.K., LaLumiere, R.T. 2018. Basolateral amygdala inputs to the medial entorhinal cortex selectively modulate the consolidation of spatial and contextual learning. Journal of Neuroscience 38, 2698-2712.

Wang, W., Zhang, L.S., Zinsmaier, A.K., Patterson, G., Leptich, E.J., Shoemaker, S.L., Yatskievych, T.A., Gibboni, R., Pace, E., Luo, H. 2019. Neuroinflammation mediates noise-induced synaptic imbalance and tinnitus in rodent models. PLoS biology 17.

Whitlock, J.R., Heynen, A.J., Shuler, M.G., Bear, M.F. 2006. Learning induces long-term potentiation in the hippocampus. science 313, 1093-1097.

Xiao, C., Liu, Y., Xu, J., Gan, X., Xiao, Z. 2018. Septal and hippocampal neurons contribute to auditory relay and fear conditioning. Frontiers in cellular neuroscience 12, 102.

Youmans, K.L., Tai, L.M., Nwabuisi-Heath, E., Jungbauer, L., Kanekiyo, T., Gan, M., Kim, J., Eimer, W.A., Estus, S., Rebeck, G.W. 2012. APOE4-specific changes in A $\beta$ accumulation in a new transgenic mouse model of Alzheimer disease. Journal of Biological Chemistry 287, 41774-41786.

Zhang, G.-W., Sun, W.-J., Zingg, B., Shen, L., He, J., Xiong, Y., Tao, H.W., Zhang, L.I. 2018. A non-canonical reticular-limbic central auditory pathway via medial septum contributes to fear conditioning. Neuron 97, 406-417. e4.

Zhang, J.S., Kaltenbach, J.A. 1998. Increases in spontaneous activity in the dorsal cochlear nucleus of the rat following exposure to high-intensity sound. Neuroscience letters 250, 197-200. 
Figure 1

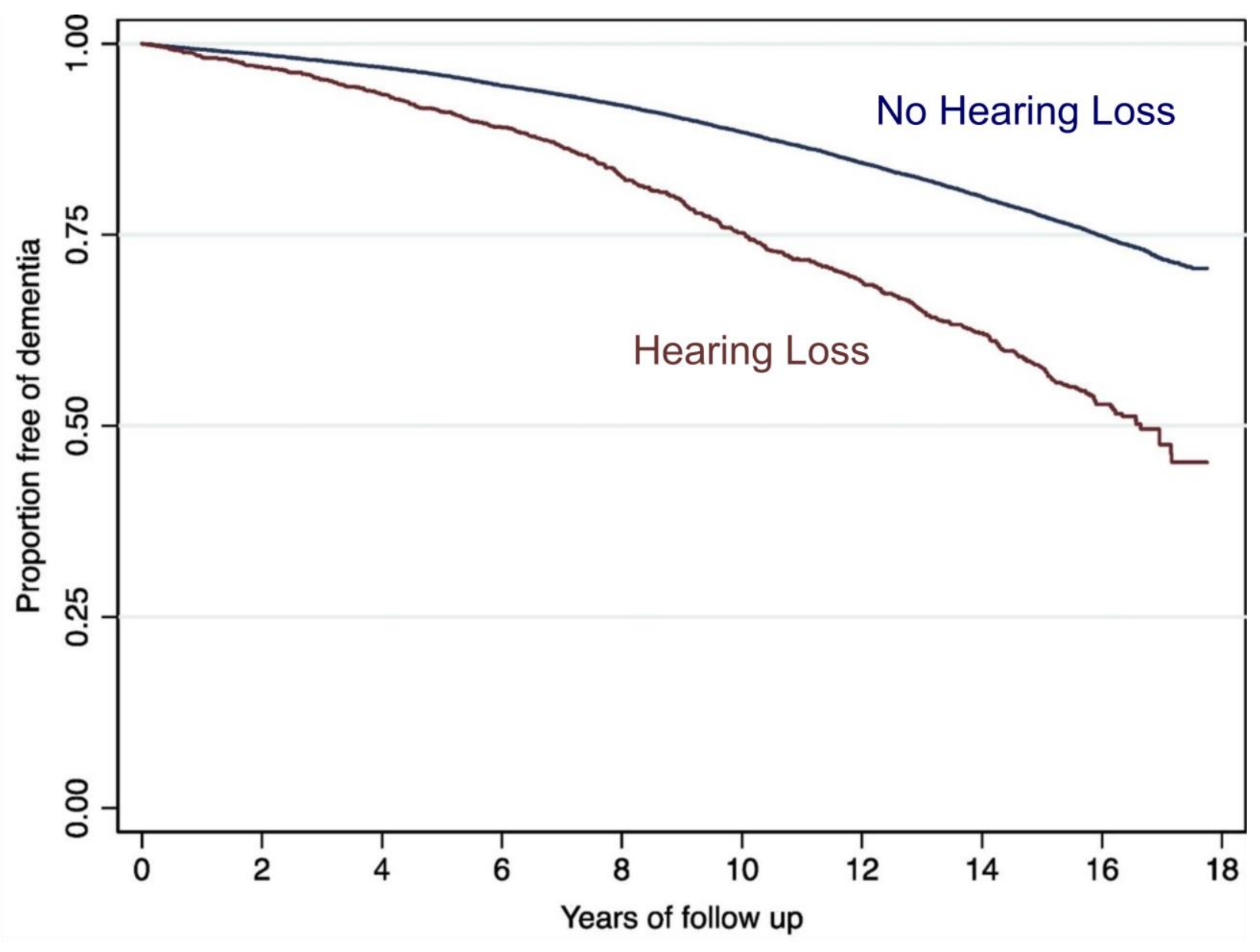


Figure 2

Interval after noise exposure in sound chamber

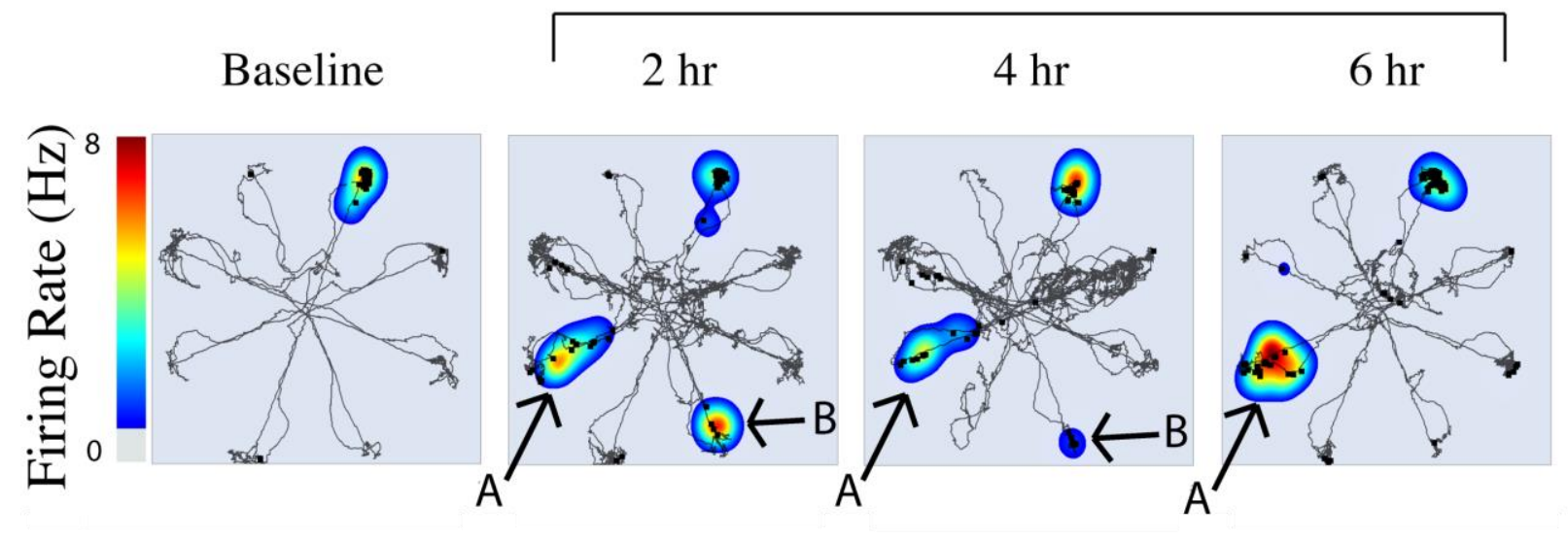


Figure 3

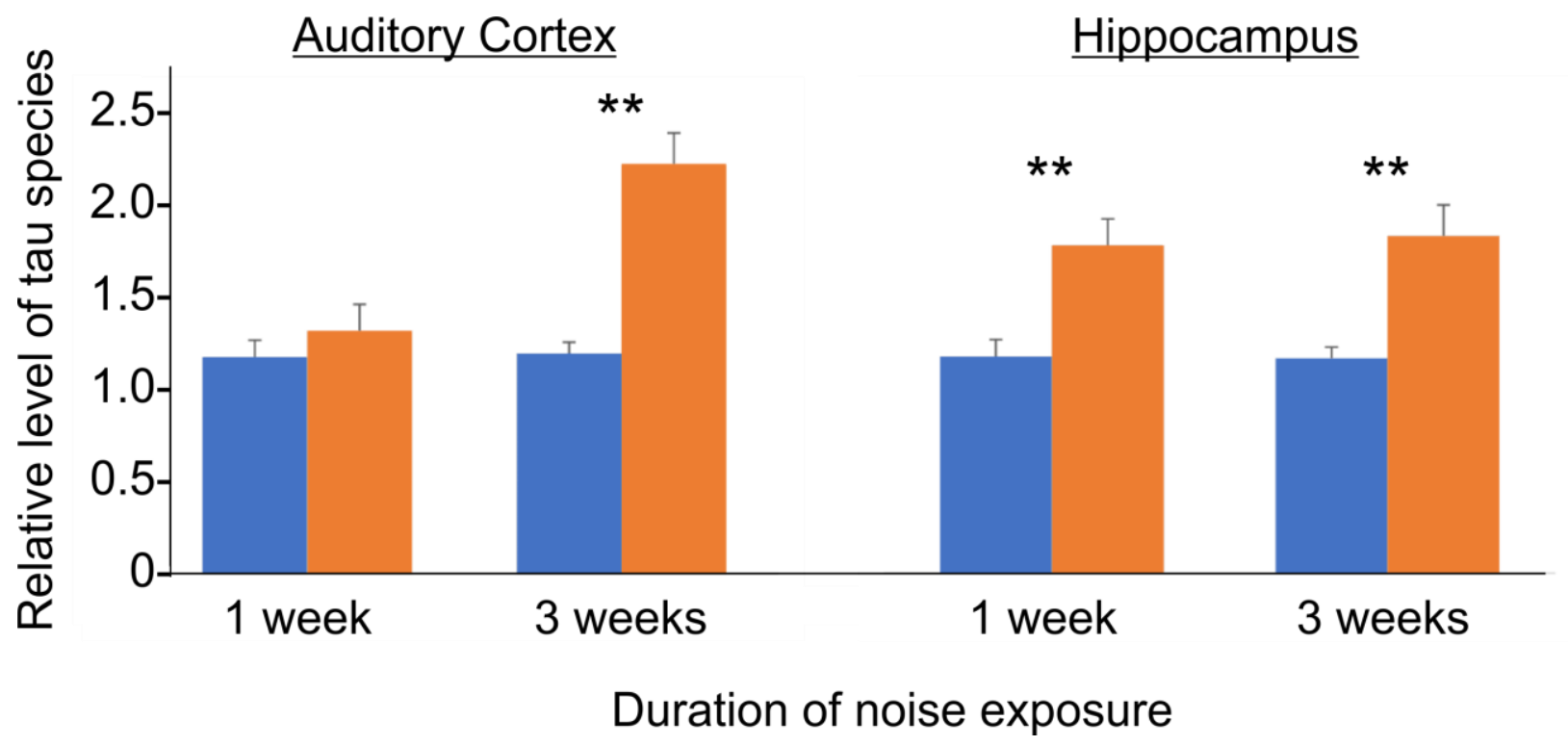


Figure 4

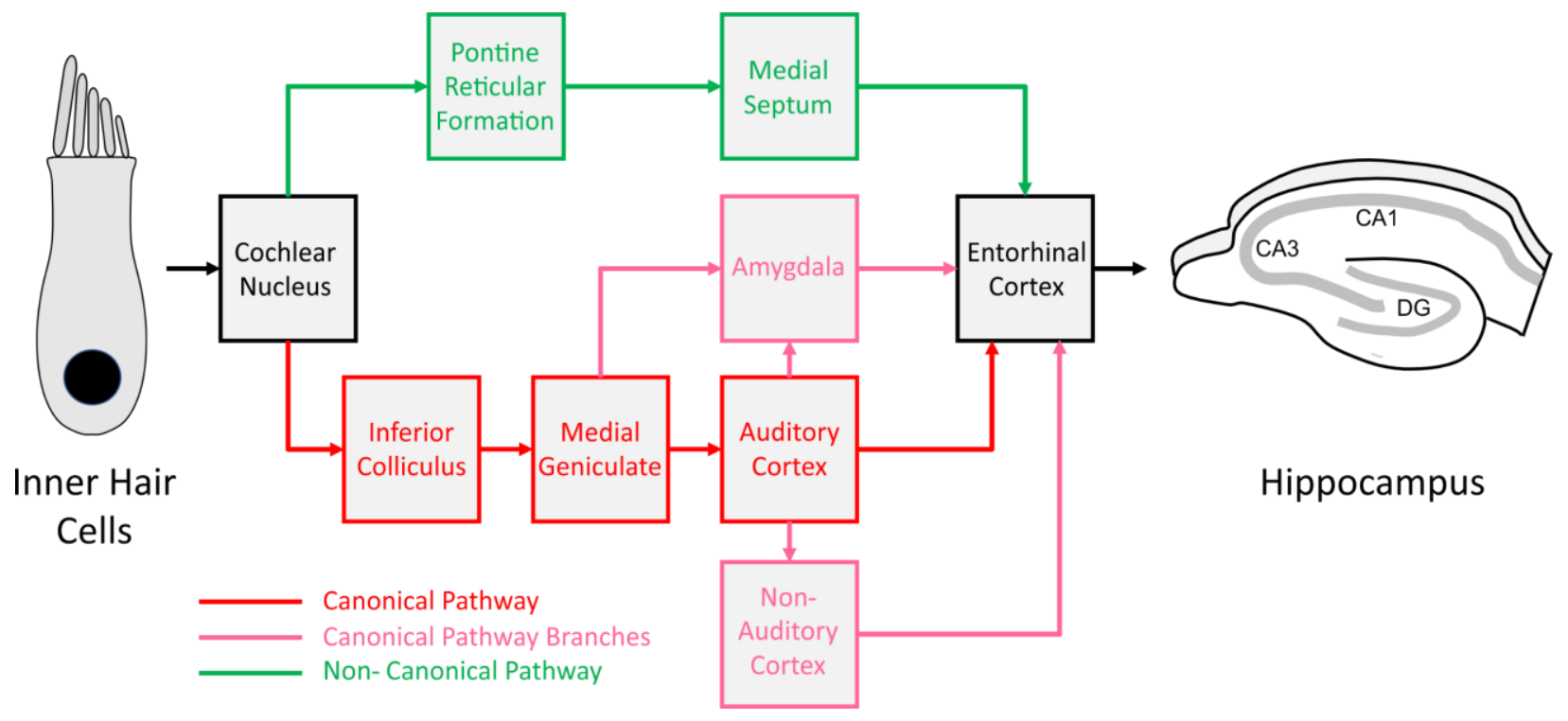


Figure 5
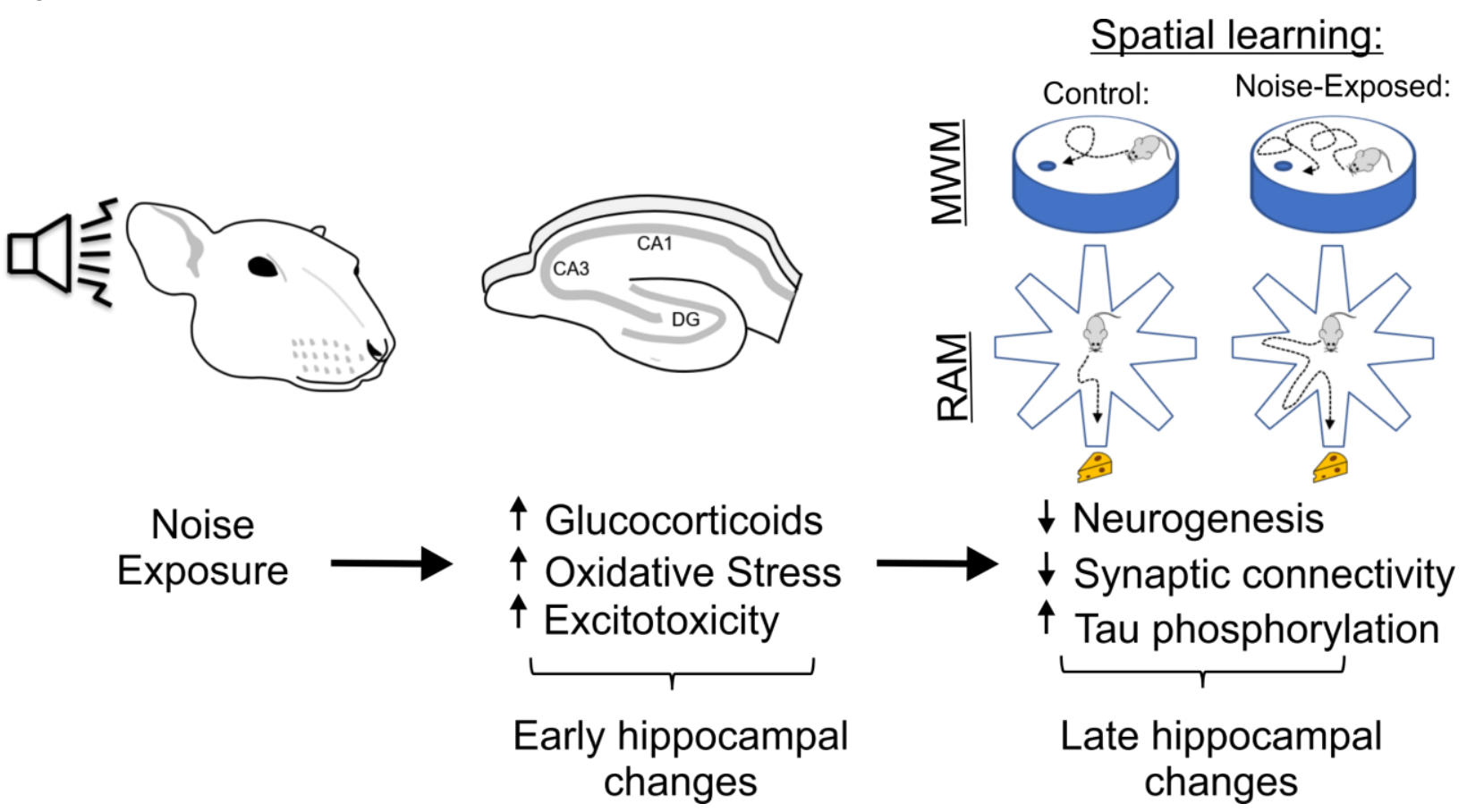


\begin{tabular}{|c|c|c|c|c|}
\hline Study & Noise Intervention & $\begin{array}{l}\text { Non-auditory behavioral } \\
\text { outcome }\end{array}$ & Other outcomes & $\begin{array}{l}\text { Assessment of peripheral auditory } \\
\text { structure or function? }\end{array}$ \\
\hline \multicolumn{5}{|c|}{\begin{tabular}{|c|c|c|} 
Acute Noise Exposure
\end{tabular}} \\
\hline $\begin{array}{l}\text { Goble et al. } \\
2009\end{array}$ & $\begin{array}{l}\text { Awake rats exposed to } 4 \mathrm{kHz} \\
\text { tone at } 104 \mathrm{~dB} \text { SPL for } 30 \\
\text { min }\end{array}$ & $\begin{array}{l}\text { Poor performance on RAM at 2- } \\
\text { 6hrs post-exposure }\end{array}$ & $\begin{array}{l}\text { Increased numbers of place fields in } \\
\text { hippocampal neurons at } 2,4 \text { or } 6 \mathrm{hrs} \\
\text { post-exposure }\end{array}$ & No. \\
\hline $\begin{array}{l}\text { Kraus et al. } \\
2010\end{array}$ & $\begin{array}{l}\text { Male rats exposed to } \\
\text { unilateral broadband noise } \\
\text { centered at } 12 \mathrm{kHz}, 126 \mathrm{~dB} \\
\mathrm{SPL} \text { under isoflurane }\end{array}$ & None measured & $\begin{array}{l}\text { Diminished numbers of neural } \\
\text { precursors and dividing cells in the } \\
\text { hippocampus at } 10 \text { weeks post- } \\
\text { exposure }\end{array}$ & $\begin{array}{l}\text { Complete loss of hair cells between } \\
20-100 \% \text { distance from the apex of the } \\
\text { cochlea }\end{array}$ \\
\hline $\begin{array}{l}\text { Cui et al. } \\
2012\end{array}$ & $\begin{array}{l}\text { Awake male rats exposed to } \\
\text { twenty } 100 \text { ms sounds at } 165 \\
\text { dB }\end{array}$ & $\begin{array}{l}\text { Diminished MWM at } 30 \text { min and } \\
3 \mathrm{hrs} \text { post-exposure. Normal } \\
\text { MWM at } 6 \text { and } 24 \text { hours. }\end{array}$ & $\begin{array}{l}\text { - Increased hippocampal glutamate } \\
\text { and aspartate up to } 24 \mathrm{hrs} \text { post- } \\
\text { exposure. No change in glycine or } \\
\text { GABA } \\
\text { - Increased hippocampal NR2B, } 30 \\
\text { min - } 24 \text { hrs } \\
\text { - Increased hippocampal ptau, 30min- } \\
\text { 24hrs PE }\end{array}$ & No. \\
\hline $\begin{array}{l}\text { Tao et al. } \\
2015\end{array}$ & $\begin{array}{l}\text { P15 awake mice exposed to } \\
\text { broadband noise at } 123 \mathrm{~dB} \\
\text { SPL for } 2 \text { hrs while awake. } \\
\text { Most energy below } 20 \mathrm{kHz}\end{array}$ & $\begin{array}{l}\text { Diminished MWM } 2 \text { months } \\
\text { later. Poor performance } \\
\text { correlated with degree of } \\
\text { hearing loss. }\end{array}$ & $\begin{array}{l}\text { Decreased number of newly } \\
\text { generated neurons in the } \\
\text { hippocampus }\end{array}$ & $\begin{array}{l}\text { Average auditory brainstem responses } \\
\text { (ABR) threshold was higher in the NE } \\
\text { group than control ( } 70.07 \text { vs. } 42.02 \mathrm{~dB} \\
\text { SPL, respectively) }\end{array}$ \\
\hline $\begin{array}{l}\text { Liu et al. } \\
2016\end{array}$ & $\begin{array}{l}\text { P45-60d awake CBA/CaJ } \\
\text { mice exposed to broadband } \\
\text { noise at } 123 \mathrm{~dB} \text { SPL for } 2 \\
\text { hrs while awake. Most } \\
\text { energy below } 20 \mathrm{kHz}\end{array}$ & $\begin{array}{l}\text { Diminished MWM } 3 \text { months } \\
\text { post-exposure, correlated with } \\
\text { degree of hearing loss }\end{array}$ & $\begin{array}{l}\text { - High serum cortisol, hippocampal } \\
\text { superoxide dismutase and } \\
\text { malondialdehyde immediately post- } \\
\text { noise, that normalized by } 1 \text { month } \\
\text { post-exposure } \\
\text { - Diminished doublecortin and Ki67 } \\
\text { cells in HC at } 3 \text { months post- } \\
\text { exposure }\end{array}$ & $\begin{array}{l}\text { Average ABR threshold was higher in } \\
\text { the NE group than control ( } 89.97 \text { vs. } \\
45.5 \mathrm{~dB} \text { SPL, respectively). }\end{array}$ \\
\hline $\begin{array}{l}\text { de Deus et } \\
\text { al. } 2017\end{array}$ & $\begin{array}{l}\text { Awake male rats exposed to } \\
80 \text { or } 100 \mathrm{~dB} \text { sound } \\
\text { (modified doorbell), } 3-15 \\
\mathrm{kHz} \text { for one minute. }\end{array}$ & $\begin{array}{l}\text { No significant change in MWM } \\
\text { or cued fear conditioning }\end{array}$ & $\begin{array}{l}\text { - Long-term potentiation in } \\
\text { hippocampal slices was diminished } \\
\text { at } 2 \text { and } 24 \text { hours post- } 100-\mathrm{dB} \\
\text { exposure, and returned to baseline } \\
\text { at } 48 \text { hours post-exposure } \\
\text { - No changes in long-term potentiation } \\
\text { with } 80 \mathrm{~dB} \text { exposure } \\
\text { - No increase in plasma } \\
\text { corticosterone compared to sham }\end{array}$ & No. \\
\hline
\end{tabular}




\begin{tabular}{|c|c|c|c|c|}
\hline & & & $\begin{array}{l}\text { controls (but elevated compared to } \\
\text { naïve) }\end{array}$ & \\
\hline $\begin{array}{l}\text { Liu et al. } \\
2018\end{array}$ & $\begin{array}{l}\text { Awake mice exposed to } \\
\text { broadband noise at } 123 \mathrm{~dB} \\
\mathrm{SPL} \text { for } 2 \mathrm{hrs} \text {. Most energy } \\
\text { below } 20 \mathrm{kHz}\end{array}$ & $\begin{array}{l}\text { Diminished MWM } 3 \text { months } \\
\text { post-exposure }\end{array}$ & $\begin{array}{l}\text { - Noise did not change stem cell bank } \\
\text { in hippocampus } \\
\text { - Noise diminished training's ability to } \\
\text { rescue newly proliferating } \\
\text { hippocampal cells and to increase } \\
\text { Npas4 levels. } \\
\text { - Noise diminished neuronal } \\
\text { morphological complexity }\end{array}$ & $\begin{array}{l}\text { ABR thresholds elevated by } \\
\text { approximately } 50 \mathrm{~dB} \text { at one and three } \\
\text { months post-NE }\end{array}$ \\
\hline $\begin{array}{l}\text { Hayes et al. } \\
2019\end{array}$ & $\begin{array}{l}\text { Isoflurane-anesthetized } \\
\text { male rats exposed to } \\
\text { narrowband noise (centered } \\
\text { at } 12 \mathrm{kHz} \text { ) at } 126 \mathrm{~dB} \text { SPL for } \\
2 \text { hours. }\end{array}$ & None measured & $\begin{array}{l}\text { - Reactive corticosterone elevated } \\
\text { one week post-exposure } \\
\text { - Increased dentate gyrus } \\
\text { glucocorticoid receptor expression } \\
10 \text { weeks post-exposure }\end{array}$ & $\begin{array}{l}\text { ABR threshold was significantly higher } \\
\text { in the left NE group compared to the } \\
\text { right non-exposed ear and the control } \\
\text { ( } 40-45 \mathrm{~dB} \text { higher). }\end{array}$ \\
\hline \multicolumn{5}{|c|}{ Acute + Subacute Noise Exposure } \\
\hline $\begin{array}{l}\text { Manikanda } \\
\text { n et al. } \\
2006\end{array}$ & $\begin{array}{l}\text { Awake male adult rats, } 100 \\
\text { dBA noise for } 4 \text { hrs/day for } \\
1,15 \text { or } 30 \text { days }\end{array}$ & $\begin{array}{l}\text { Diminished RAM performance } \\
\text { from 1-30 days post-exposure }\end{array}$ & $\begin{array}{l}\text { - Diminished distal dendritic count in } \\
\text { hippocampus } \\
\text { - Increased corticosterone with acute } \\
\text { noise, less of an increase with } 30 \\
\text { days noise } \\
\text { - Increase in hippocampal LPO, } \\
\text { superoxide dismutase, catalase and } \\
\text { acetylcholinesterase and drop in } \\
\text { GSH, generally worse immediately } \\
\text { after } 1 \text { day and closer to normal after } \\
30 \text { days noise-exposure }\end{array}$ & No. \\
\hline $\begin{array}{l}\text { Uran et al. } \\
2010\end{array}$ & $\begin{array}{l}15 \text { day old awake male rats } \\
\text { exposed to } 95-97 \mathrm{~dB} x \\
2 \mathrm{~h} / \text { day for } 1 \text { or } 15 \text { days }\end{array}$ & $\begin{array}{l}\text { - Worsened performance on } \\
\text { RAM task, was generally } \\
\text { worse with chronic exposure, } \\
\text { assessed } 30 \text { day post- } \\
\text { exposure } \\
\text { - Chronic exposure caused } \\
\text { diminished performance in an } \\
\text { open-field task. }\end{array}$ & $\begin{array}{l}\text { - Acute noise led to a decrease in } \\
\text { hippocampal reactive oxygen } \\
\text { species, an increase in superoxide } \\
\text { dismutase and an increase in } \\
\text { catalase. } \\
\text { - All of these values trended towards } \\
\text { normalizing in the subacute group. }\end{array}$ & No. \\
\hline $\begin{array}{l}\text { Uran et al. } \\
2012\end{array}$ & $\begin{array}{l}\text { Awake male adult rats } \\
\text { exposed to } 95-97 \mathrm{~dB} \text { SPL, } \\
2 \mathrm{~h} / \text { day for one day or } 15 \\
\text { days }\end{array}$ & $\begin{array}{l}\text { Diminished performance on } \\
\text { open-field and novel object } \\
\text { recognition at times immediately }\end{array}$ & $\begin{array}{l}\text { - Acute exposure increased the } \\
\text { number of total (small increase) and } \\
\text { pyknotic (large increase) cells in the }\end{array}$ & No. \\
\hline
\end{tabular}




\begin{tabular}{|c|c|c|c|c|}
\hline & & $\begin{array}{l}\text { post exposure and at } 15 \text { days } \\
\text { post-exposure }\end{array}$ & $\begin{array}{l}\text { CA1 and CA3 regions of } \\
\text { hippocampus } \\
\text { - Subacute exposure increased total } \\
\text { cells in CA3 and dentate gyrus and } \\
\text { increased pyknotic cells only in CA3 }\end{array}$ & \\
\hline \multicolumn{5}{|c|}{ Subacute Noise Exposure } \\
\hline $\begin{array}{l}\text { Rabat et al. } \\
2006\end{array}$ & $\begin{array}{l}\text { Awake male rats were } \\
\text { exposed to a high-frequency } \\
\text { adaptation of noise of a } \\
\text { French aircraft carrier } \\
\text { ranging from } 70 \mathrm{~dB} \\
\text { background with peaks of } \\
85-103 \mathrm{~dB} \text { with global } \\
\text { intensity of } 88 \mathrm{~dB} \text { for } 9 \text { days, } \\
24 \text { hr/day }\end{array}$ & $\begin{array}{l}\text { Two-trial long-term memory test } \\
\text { performance diminished one day } \\
\text { post-exposure. Their } \\
\text { vulnerability to noise exposure } \\
\text { was predicted by their reactivity } \\
\text { to novelty. }\end{array}$ & $\begin{array}{l}\text { Vulnerable rats showed a decrease in } \\
\text { slow wave sleep. Poor slow wave } \\
\text { sleep was predictive of poor long-term } \\
\text { memory performance. }\end{array}$ & No. \\
\hline $\begin{array}{l}\text { Cui et al. } \\
2009\end{array}$ & $\begin{array}{l}\text { Adult awake male rats } \\
\text { exposed to } 100 \mathrm{~dB} \text { white } \\
\text { noise for } 4 \mathrm{~h} / \text { day for } 30 \text { days. }\end{array}$ & $\begin{array}{l}\text { MWM with training done on days } \\
26-29 \text { and probe trial on day } 30 . \\
\text { Performance in noise group was } \\
\text { significantly diminished. }\end{array}$ & $\begin{array}{l}\text { - HPLC measurements in } \\
\text { hippocampal homogenates showed } \\
\text { increased glutamate, decreased } \\
\text { GABA and no change in aspartate or } \\
\text { glycine in noise-exposure groups. } \\
\text { - Nissl bodies were decreased in the } \\
\text { CA1 and dentate gyrus with a trend } \\
\text { toward decrease in CA3 } \\
\text { - Decrease in NR2B expression in } \\
\text { CA1, CA3 and dentate gyrus }\end{array}$ & No. \\
\hline $\begin{array}{l}\text { Chengzhi et } \\
\text { al. } 2011\end{array}$ & $\begin{array}{l}\text { Awake male rats exposed to } \\
80 \mathrm{~dB} \text { or } 100 \mathrm{~dB} \text { for } 4 \mathrm{~h} / \mathrm{day} \\
\text { for } 30 \text { days }\end{array}$ & $\begin{array}{l}\text { Dose-dependent increased in } \\
\text { escape latency on MWM, that } \\
\text { improved from } 1 \text { to } 40 \text { days } \\
\text { post-exposure }\end{array}$ & $\begin{array}{l}\text { HPLC measurements of hippocampal } \\
\text { homogenates with dose-dependent } \\
\text { decreases in norepinephrine, } \\
\text { serotonin and dopamine that also } \\
\text { improve from day } 1 \text { to } 40 \text { days post- } \\
\text { exposure }\end{array}$ & No. \\
\hline $\begin{array}{l}\text { Cheng et } \\
\text { al. } 2011\end{array}$ & $\begin{array}{l}\text { Awake male mice were } \\
\text { exposed to } 80 \mathrm{~dB} \text { SPL noise } \\
\text { for } 2 \mathrm{~h} / \text { day for } 1,3 \text { or } 6 \\
\text { weeks }\end{array}$ & $\begin{array}{l}\text { Duration of exposure-dependent } \\
\text { decrease in learning in MWM } \\
\text { and inhibitory avoidance testing. }\end{array}$ & $\begin{array}{l}\text { Six weeks of noise-exposure } \\
\text { caused a drop in the superoxide } \\
\text { dismutase / malondialdehyde ratio } \\
\text { in inferior colliculus, auditory cortex } \\
\text { and hippocampus, and this drop } \\
\text { was strongest in the hippocampus. } \\
\text { Six weeks of noise exposure also } \\
\text { increased ptau and diminished } \\
\text { unphosphorylated tau in the } \\
\text { hippocampus }\end{array}$ & No. \\
\hline
\end{tabular}




\begin{tabular}{|c|c|c|c|c|}
\hline & & & $\begin{array}{l}\text { - Tau levels correlated with MWM } \\
\text { latency, while ptau levels inversely } \\
\text { correlated with MWM latency }\end{array}$ & \\
\hline $\begin{array}{l}\text { Jauregui- } \\
\text { Huerta et } \\
\text { al. } 2011\end{array}$ & $\begin{array}{l}\text { Awake male rats exposed to } \\
15 \text { days of noise PND 21-35 } \\
\text { using audiogram-fitted } \\
\text { adaptation of noisy } \\
\text { environment, } 70 \mathrm{~dB} \\
\text { background with peaks } 85- \\
103 \mathrm{~dB}\end{array}$ & None measured & $\begin{array}{l}\text { - Noise-exposure caused mild } \\
\text { decrease in weight } \\
\text { - Noise-exposure increased } \\
\text { corticosterone at } 1 \text { day post- } \\
\text { exposure, but not } 54 \text { days post- } \\
\text { exposure } \\
\text { - Noise-exposure decreased } \\
\text { bromodeoxyuridine+ cells in dentate } \\
\text { gyrus and CA3 of hippocampus at } \\
54 \text { days post-exposure }\end{array}$ & No. \\
\hline $\begin{array}{l}\text { Haider et } \\
\text { al. } 2012\end{array}$ & $\begin{array}{l}\text { Awake male rats exposed to } \\
100 \mathrm{~dB} \text { noise for } 4 \mathrm{hrs} / \text { day } \\
\text { for } 15 \text { days }\end{array}$ & $\begin{array}{l}24 \text { hours after last noise- } \\
\text { exposure, rats have poor } \\
\text { learning and retention on an } \\
\text { elevated plus maze task and } \\
\text { poor recognition memory on } \\
\text { novel object recognition task. }\end{array}$ & $\begin{array}{l}\text { One hour after behavioral testing there } \\
\text { was a decrease in hippocampal } \\
\text { dopamine and serotonin with increase } \\
\text { in turnover rates for each }\end{array}$ & No. \\
\hline $\begin{array}{l}\text { Cui et al. } \\
2013\end{array}$ & $\begin{array}{l}\text { Awake male rats exposed to } \\
\text { noise } 100 \mathrm{~dB} \text { SPL } \\
4 \mathrm{~h} / \text { dayx } 30 \text { days. }\end{array}$ & None measured & $\begin{array}{l}\text { All assessments done immediately } \\
\text { after the last noise exposure: } \\
\text { - NR2B diminished (Western blot) in } \\
\text { hippocampus } \\
\text { - pTau increased in hippocampus } \\
\text { (Western blot) } \\
\text { - TUNEL-positive cells seen in } \\
\text { hippocampus }\end{array}$ & No. \\
\hline $\begin{array}{l}\text { Li et al. } \\
2014\end{array}$ & $\begin{array}{l}\text { Awake male rats exposed to } \\
\text { noise } 400-6300 \mathrm{~Hz} \text { at } 100 \\
\mathrm{~dB} \text { SPL } 4 \text { hours/day for } 14 \\
\text { days }\end{array}$ & None measured & $\begin{array}{l}\text { - Noise-exposure caused an increase } \\
\text { in hippocampal tau phosphorylation } \\
\text { that was mitigated by systemic } \\
\text { administration of the NMDA-receptor } \\
\text { antagonist MK-801 } \\
\text { - MK-801 also diminished } \\
\text { hippocampal expression of glycogen } \\
\text { synthase kinase-3ß, which was } \\
\text { increased by noise }\end{array}$ & No. \\
\hline $\begin{array}{l}\text { Cheng et } \\
\text { al. } 2016\end{array}$ & $\begin{array}{l}\text { 3-week old mice exposed to } \\
80 \mathrm{~dB} \text { SPL noise }(10 \mathrm{~Hz}- \\
10 \mathrm{kHz}) \times 2 \mathrm{~h} / \text { day for } 1-3 \\
\text { weeks }\end{array}$ & None measured & $\begin{array}{l}\text { - Noise-exposure led to increase in } \\
\text { malondialdehyde and decrease in } \\
\text { superoxide dismutase in HC in } 1 \text { and } \\
3 \text { week groups, but caused the same }\end{array}$ & No. \\
\hline
\end{tabular}




\begin{tabular}{|c|c|c|c|c|}
\hline & & & $\begin{array}{l}\text { in the auditory cortex only in the } 3 \\
\text { week group. } \\
\text { Noise-exposure led to drop in } \\
\text { unphosphorylated tau and increase } \\
\text { in ptau in the hippocampus at } 1 \text { and } \\
3 \text { weeks and in the auditory cortex } \\
\text { only at } 3 \text { weeks }\end{array}$ & \\
\hline $\begin{array}{l}\text { Park et al. } \\
2016\end{array}$ & $\begin{array}{l}\text { One month old awake male } \\
\text { mice exposed to } 110 \mathrm{~dB} \\
\mathrm{SPL} \text { white noise for } 60 \\
\mathrm{~min} / \text { day } \times 20 \text { days }\end{array}$ & $\begin{array}{l}\text { At } 6 \text { months the NE animals } \\
\text { showed increased total trial time } \\
\text { and working memory errors and } \\
\text { lowered correct entry ratios on } \\
\text { RAM, as well as diminished } \\
\text { discrimination index measured } \\
\text { using novel object recognition. }\end{array}$ & & $\begin{array}{l}\text { Average ABR threshold was } \\
\text { approximately } 30 \mathrm{~dB} \text { higher in the NE } \\
\text { group than control at } 6 \text { months post- } \\
\text { NE. }\end{array}$ \\
\hline $\begin{array}{l}\text { Gai et al. } \\
2017\end{array}$ & $\begin{array}{l}\text { Awake male rats exposed to } \\
95 \mathrm{~dB} \text { SPL white noise for } 4 \\
\text { hours/day for } 20 \text { days. }\end{array}$ & None measured & $\begin{array}{l}\text { Corticotropin-releasing factor receptor } \\
\text { levels increased in hippocampus } \\
\text { immediately after exposure, and } \\
\text { trended towards control levels over } \\
\text { subsequent } 14 \text { days, despite } \\
\text { persistent increased in p-tau. }\end{array}$ & No. \\
\hline $\begin{array}{l}\text { Park et al. } \\
2018\end{array}$ & $\begin{array}{l}\text { One month old awake male } \\
\text { mice exposed to } 110 \mathrm{~dB} \\
\mathrm{SPL} \text { white noise for } 60 \\
\mathrm{~min} / \text { day } \times 20 \text { days }\end{array}$ & $\begin{array}{l}\text { - Performance on RAM (working } \\
\text { memory errors and correct } \\
\text { entry ratios) worsened up to } 9 \\
\text { months post-exposure, then } \\
\text { improved for working memory } \\
\text { errors at } 12 \text { months. } \\
\text { - Discrimination index on novel } \\
\text { object recognition was worse } \\
\text { at } 12 \text { months post-exposure }\end{array}$ & $\begin{array}{l}\text { Ptau and lipofuscin granule total area } \\
\text { increased in the hippocampus }\end{array}$ & $\begin{array}{l}\text { Average ABR threshold was } \\
\text { significantly higher in the NE group } \\
\text { than control at } 1 \text {-day, } 3,6 \text {, and } 9 \\
\text { month post-NE, but the difference } \\
\text { gradually decreased at } 12 \text { months } \\
\text { post-NE. ABR thresholds at } 12 \text { months } \\
\text { post-NE did not differ for click and } 32 \\
\text { kHz tone, but the } 8 \text { and } 16 \mathrm{kHz} \text { tones } \\
\text { were higher in the NE groups. }\end{array}$ \\
\hline $\begin{array}{l}\text { Shukla et } \\
\text { al. } 2019\end{array}$ & $\begin{array}{l}\text { Male awake rats exposed to } \\
100 \mathrm{~dB} \text { SPL white noise } \\
2 \mathrm{~h} / \text { day for } 15 \text { days. Animals } \\
\text { assessed } 15 \text { days after } \\
\text { noise exposure. }\end{array}$ & $\begin{array}{l}\text { Noise-exposed animals had } \\
\text { longer latency and path length in } \\
\text { MWM test. }\end{array}$ & $\begin{array}{l}\text { - Diminished doublecortin- and Ki67- } \\
\text { positive cells in hippocampus } \\
\text { - Increase in serum corticosterone } \\
\text { levels } \\
\text { - Adenosine receptor A2A agonist } \\
\text { given during noise exposure } \\
\text { mitigated all of these changes, } \\
\text { including hearing loss and hair cell } \\
\text { loss }\end{array}$ & $\begin{array}{l}\text { - ABRs to clicks at } 15 \text { days post- } \\
\text { exposure were elevated from } 34.6 \\
\text { dB SPL to } 50.83 \mathrm{~dB} \text { SPL. } \\
\text { - There was } 45-50 \% \text { loss of outer hair } \\
\text { cells in the apical and basal regions } \\
\text { of the cochlea. } \\
\text { - Approximately } 19 \% \text { drop in density } \\
\text { of inner hair cell ribbon synapses }\end{array}$ \\
\hline
\end{tabular}

Table 1: Summary of studies reviewed. See text for details. ptau = phosphorylated tau, $A B R=$ auditory brainstem responses, NE $=$ noise exposure. 